\title{
SECURED LENDING STIMULANTS: The Role and Effects of Public Credit GUARANTEES IN JAPAN
}

\author{
Marek Dubovec and Shogo Owada ${ }^{\dagger}$
}

\begin{abstract}
Access to credit is crucial for business growth, and particularly for small and medium-sized enterprises (SMEs). Two mechanisms are widely utilized in economies around the world to channel credit to the SME sector: (i) market-based financing facilitated through secured transactions frameworks, and (ii) government-supported financing through public guarantee schemes. Secured transactions frameworks reduce credit risk by providing the lender with the right to apply the proceeds of the collateral in priority over other creditors. Public guarantee schemes undertake to pay a percentage of the owed amount to the lender upon default of the borrower. The different nature of these protections offers lenders distinct incentives to engage in each type of credit transaction.
\end{abstract}

Guarantee schemes are a viable countercyclical mechanism to address the economic fallout from extraordinary events, including COVID-19. However, their effectiveness during ordinary times has been questioned. While quantitatively such schemes enable a large swath of enterprises to access credit at low rates, qualitatively they channel funds to unproductive borrowers, prolong the existence of SMEs that should be liquidated, and disadvantage ineligible enterprises. In proportion to gross domestic product, Japanese SMEs are the largest users of guarantee schemes in the world. OECD and

$\dagger$ Marek Dubovec is the Executive Director of the Kozolchyk National Law Center (NatLaw), Tucson, Arizona, and Part-Time Professor of Practice, James E. Rogers College of Law, the University of Arizona. Shogo Owada is a former researcher of the Institute of Monetary and Economic Studies, Bank of Japan. The authors would like to thank Charles W. Mooney, Jr., Megumi Hara, Giuliano G. Castellano, Hideki Kanda, Masayoshi Hirano and staff from Institute of Monetary and Economic Studies for their suggestions and insightful comments and Perla Amaya for her excellent editorial suggestions. All errors are ours. 
IMF studies found that public guarantees result in weak profitability, low productivity, and high leverage. At the same time, they disincentivize financial institutions from investing in credit screening, valuation, and monitoring techniques necessary to deploy marketbased financing products.

This article identifies the negative effects of the Japanese guarantee scheme and advocates for modifications to aid the development of market-based financing. It suggests elimination of the incentives for both the financial institutions and borrowers to continuously utilize this form of government-supported financing that sustains zombie companies. Several recommendations are made to induce participating financial institutions to develop expertise in the valuation, monitoring, and disposal of collateral, so as to pave the way for a transition of viable borrowers to market-based financing. However, this transition requires a modern secured transactions legal regime that Japan presently lacks. This article contributes to the research and policy debates undertaken within several on-going projects that seek to modernize the Japanese legal framework to facilitate secured transactions.

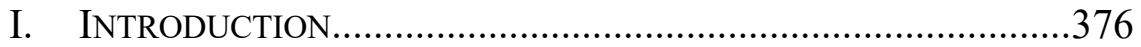

II. STATE INTERVENTIONS IN CREDIT MARKETS: ARE THEY INCENTIVIZING ACCESS TO CREDIT? ......................................382

III. SME LENDING IN JAPAN: CONDITIONS AND LAW …….............386

Lending Conditions ............................................................... 387

Secured Transactions Frameworks: International

Principles and Japan ……………………………........391

IV. Credit Guarantee Schemes: Evolution, Governing

PRINCIPLES, TYPES, AND THE JAPANESE STRUCTURE ..............395

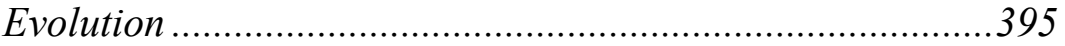

International Perspectives ....................................................397

Types of Credit Guarantee Schemes ......................................399

Regulatory Treatment of Guaranteed Loans..........................402

Operational Structure of the Japanese Credit

Supplementation System ……………………………......406

Credit Guarantee Programs During Crises..........................411

V. EFFECTS OF GUARANTEES......................................................

Borrowers and Lenders....................................................418

Realignment of the Incentives .............................................421

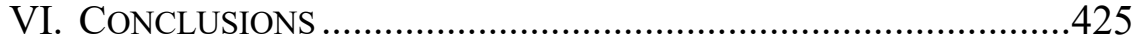




\section{INTRODUCTION}

It has been said that the contribution of financial markets to economic growth is "almost too obvious for serious discussion." Financial markets are composed of multiple elements that channel credit to the economy. This article focuses on the types of financial market instruments through which small and medium-sized enterprises (SMEs) access credit. The obviousness of the statement about the contribution of financial markets to economic growth is put to a test in examining the credit market for SMEs in Japan.

Because of their broad role in the economy, SME development is key to productivity and inclusive growth. ${ }^{2}$ As the engine for SME development and economic growth overall, access to credit is crucial. ${ }^{3}$ Establishing an environment that enables access to credit entails developing a modern credit infrastructure, introducing innovative credit products, removing barriers to financial services, and formalizing SMEs for inclusion in the formal sector. ${ }^{4}$ This

\footnotetext{
${ }^{1}$ Merton H. Miller, Financial Markets and Economic Growth, $11 \mathrm{~J}$. Applied CoRp. Fin. 8, 14 (1998). See also Ben R. Craig et al., Credit Market Failure Intervention: Do Government Sponsored Small Business Credit Programs Enrich Poorer Areas?, 30 SMALl Bus. ECON. 345 (2008) ("economic growth and financial market development tend to be positively correlated"). But see Robert E. Lucas Jr., On the Mechanics of Economic Development, 22 J. MONETARY ECON. 3, 6 (1988) (expressing a contrasting viewpoint that the importance of financial markets is "very badly over-stressed").

${ }^{2}$ See Angel Gurría, 2018 OECD SME Ministerial Conference, ORG. FOR ECON. CoOP. \& DEv (OECD) (Nov. 22, 2018), https://www.oecd.org/social/oecdsme-ministerial-conference-mexico-2018.htm [https://perma.cc/9C2Y-87Q8] ] ("SEMs are key to strengthening productivity"); INT'L. FIN. CORP., MSME FinANCE GAP: AsSESSMENT OF THE SHORTFALlS AND OPPORTUNITIES IN FinANCING Micro, SMALl, AND MEdium ENTERPRISES IN EMERging MARKETS, at 1 (2017) ("[Micro, small, and medium enterprises] in emerging markets are widely believed to be the engine of growth.").

3 See Int'l. Fin. Corp. (IFC), Secured Transactions, Collateral Registries and Movable Asset-Based Financing Knowledge Guide, at 4 (Nov. 2019) (stating that greater access to credit would generate positive impact on producitivity and economic growth).

${ }^{4}$ See Id.
} 
infrastructure is composed of private law, regulatory rules, and various practical aspects that need to be adequately coordinated. ${ }^{5}$

Business growth and entrepreneurship are important for economic development. ${ }^{6}$ Several factors affect the prospect of business growth, fostering innovation and entrepreneurship. Restricted access to credit is consistently found to be a major impediment for SMEs. ${ }^{7}$ SMEs face higher transactional costs due to their opaqueness and lack of adequate collateral. ${ }^{8}$ In Japan, more than $99 \%$ of all businesses are SMEs, providing more than $70 \%$ of private sector jobs. ${ }^{9}$ Availability of credit, its duration or cost is not

\footnotetext{
${ }^{5}$ See Giuliano G. Castellano \& Marek Dubovec, Credit Creation: Reconciling Legal and Regulatory Incentives, 81 L. \& CONTEMP. PROBS. 63 (2018) [hereinafter Castellano \& Duvobec, Credit Creation] (discussing the necessity of coordinating between legal and regulatory standards to promote access to credit); Giuliano G. Castellano \& Marek Dubovec, Global Regulatory Standards and Secured Transactions Law Reforms: At the Crossroad Between Access to Credit and Financial Stability, 41 FordHAM InT'L L.J. 531, 532 (2018) [hereinafter Castellano \& Dubovec, Global Regulatory Standards] ("Oscillating between the need of expanding credit creation to promote economic growth and the urgency of controlling the excessive accumulation of debt, modern economies depend on private law rules and regulatory provisions that originate in different fora of the international lawmaking arena."); Giuliano G. Castellano \& Marek Dubovec, Bridging the Gap: The Regulatory Dimension of Secured Transactions Law Reforms, 22 UNIF. L. REV. 663 (2017) [hereinafter Castellano \& Dubovec, Bridging the Gap] ("The lack of coordination between secured transactions law and capital requirements generates tensions in the legal framework governing extension of credit secued by movable assets.").

${ }^{6}$ Thorsten Beck, Bank Financing for SMEs-Lessons From the Literature, 225 NAT'L. INST. ECON. REV. 23, 34 (2013).

${ }^{7} \mathrm{Id}$. at 25 .

${ }^{8}$ Pietro Calice, Assessing Implementation of the Principles for Public Credit Guarantees for SMEs: A Global Survey 5 (World Bank Grp. (WBG), Pol'y Rsch. Working Paper No. 7753, 2016), https://openknowledge.worldbank.org/bitstream/handle/10986/24834/Assessing0i mpl0Es000a0global0survey.pdf? sequence $=1 \&$ isAllowed $=y$ [https://perma.cc/2UYP-ZH8G].

${ }^{9}$ Financing SMEs and Entrepreneurs 2019: An OECD Scoreboard, OECD PUBLISHING, at 143 (Apr. 12, 2019), https://doi.org/10.1787/fin_sme_ent-2019-en [https://perma.cc/7FDN-Z8DN] (citing 2014 statistics). See also Mariana Colacelli \& Gee Hee Hong, Productivity Drag from Small and Medium-Sized Enterprises in Japan, INT'L MONETARY FUND (IMF), at 3 (2019) (citing that SMEs more than $70 \%$ of Japan's total work force) .
} 
however a problem in Japan. ${ }^{10}$ Its nature and the channel through which it is extended are problematic, dampening growth and preserving zombie companies. ${ }^{11}$

A market failure, such as the lack of information on borrowers may result in inefficient allocation of credit. ${ }^{12}$ Such a failure may then become an economic justification for a government-sponsored lending or guarantee program. ${ }^{13}$ Various state interventions have been implemented across jurisdictions to prop up SME financing. These include co-financing or risk-mitigation facilities, such as guarantee schemes, direct lending programs, facilities for the pledging of SME loans as collateral against refinancing from the central bank, tax and interest rate subsidies. ${ }^{14}$ Some of these interventions originated as countercyclical measures, but gradually became entrenched. ${ }^{15}$ The case for deploying a particular intervention, including a guarantee scheme to address the failure of inadequate access to credit instead of some other intervention has not been made. ${ }^{16}$

Market-based and government-supported financing are the two main credit access channels for SMEs. The former is facilitated by secured transactions frameworks and the latter through public guarantee schemes. Both mechanisms reduce the credit risk of

\footnotetext{
${ }^{10}$ See Fin. Stability BD., Evaluation OF THE EFFECTS OF FINANCIAL REGULATORY REFORMS ON SMALL AND MEDIUM-SIZED ENTERPRISE (SME) FINANCING 12-13 (2019) [hereinafter FSB, EvALUATION] (showing that three quarters of all Japanese SME loans have maturity over one year and an interest rate of around $1 \%$ ).

${ }^{11}$ In a 2019 report, the International Monetary Fund (IMF) concluded that "the overly generous public guarantee schemes in Japan reduce the incentives for non-viable businesses to exit, contributing to the survival of inefficient, small and old enterprises." Colacelli \& Hong, supra note 9, at 8.

12 Joseph E. Stiglitz \& Andrew Weiss, Credit Rationing in Markets with Imperfect Information, 71 AM. ECON. REV. 393, 409 (1981).

13 See Craig et al., supra note 1, at 345, 348 ("The economic justification for any government-sponsored small business lending program or loan guarantee program must rest on a generally acknowledged failure of the private sector to allocate loans efficiently.").

${ }^{14}$ FSB, EvaluATION, supra note 10, at 2. For a discussion of preferential interest rates, see António Antunes et al., The Effects of Credit Subsidies on Development, 58 ECON. THEORY 1 (2015).

${ }^{15}$ FSB, Evaluation, supra note 10, at 2.

16 Augusto de la TORRE ET AL., INNOVATIVE EXPERIENCES IN ACCESS TO FINANCE: MARKET-FrIENDLy Roles FOR THE Visible HAND? 196 (2017).
} 
lenders, including non-recovery and insolvency, but in different ways. ${ }^{17}$ Market-based financing products provide the lender with access to an asset (collateral) that may be disposed of upon default of the borrower with priority over other creditors of the same borrower. Government-supported financing reduces the risk of the lender by payment of a percentage of the owed amount upon default of the borrower, whether or not collateral has been taken by the lender. The different nature of the credit risk mitigant also affects the behavior of lenders and borrowers differently.

Inefficient legal frameworks for secured transactions may be a justification for the heavy reliance on public credit guarantees. ${ }^{18}$ If guarantee schemes are established or supported with the objective of addressing market failure, they should be structured to lead to the establishment of market-based financing. Such a structure presupposes building lender capacity, generating relevant data on the collateral, and aiding regulatory compliance. ${ }^{19}$

The use of collateral increases borrowers' incentives to conduct commercial activities in a manner that maximizes revenues. This is because the provision of collateral shifts the risk of losses to the borrower, enhancing motivation to repay the loan. In contrast, a guaranteed loan that is not secured with any assets provides less motivation to repay the loan. This is especially the case where the culture, reinforced by the guarantee scheme design, dis-incentivizes termination of the lending relationship. In Japan, borrowers are rarely forced into insolvency or their assets liquidated. ${ }^{20}$ Instead, financial institutions restructure the loan, with support from the guarantee scheme, preserving the existence of a zombie company. This negatively affects the company, its healthy competitors, causing

${ }^{17}$ See Elizabeth Warren \& Jay Lawrence Westbrook, Contracting out of Bankruptcy: An Empirical Intervention, 118 HARV. L. REV. 1197, 1217 (2005) (arguing that security interests enable shifting of the insolvency risk onto other creditors).

${ }^{18}$ DE LA TORRE ET AL., supra note 16.

${ }^{19}$ See Castellano \& Dubovec, Bridging the Gap, supra note 5; U.S. AGENCY FOR INT'L. DEV., From LAWS TO LOANS: OPPORTUNITIES AND CHALLENGES IN ACHIEVING the Promise OF SeCured LeNDing Reforms 37 (2018) [hereinafter USAID, FROM LAWS TO LOANS] ("[G]uarantees should be scoped to work in unison with other programs and policies to encourage lending practices that help move both lenders and individual borrowers off guarantees over time, enabling the redirection of remaining resources to new customers and needs.").

${ }^{20}$ See infra Section III(0). 
distortions in the overall market. ${ }^{21}$ A study of Japanese firms that used guaranteed loans concluded that:

Generous guarantees likely helped firms that had fundamental difficulties but did not conduct serious restructurings, so-called "Zombie" firms, to remain alive. The existence of Zombies decreases the efficiency of the economy. . . . The Japanese government must hurry to rebuild a credit guarantee system that makes clear whom it should support, and encourages firms and banks to make an effort to increase efficiency and competitiveness. ${ }^{22}$

The impact of guarantee schemes on secured lending has been studied globally, ${ }^{23}$ including in Japan. ${ }^{24}$ In some economies, the schemes have been popular finance mechanisms and considered the most effective government support program for SME lending. ${ }^{25}$ However, an assessment of sixty credit guarantee schemes in fiftyfour countries, twenty-two of which were high-income economies, including Japan, confirmed that improperly designed schemes could be costly and provide limited value. ${ }^{26}$

Guarantee schemes are, by far, the most prevalent mechanism supporting the credit needs of Japanese businesses. In proportion to its gross domestic product (GDP), Japan is the largest user of public

${ }^{21}$ See Ricardo J. Caballero et al., Zombie Lending and Depressed Restructuring in Japan, 98 AM. ECON. REV. 1943, 1944 (2008) (indicating that the phenomenon of zombie firms and zombie banks emerged in the 1990s).

${ }^{22}$ Nobuyoshi Yamori, Japanese SMEs and the Credit Guarantee System After the Global Financial Crisis, 3 CoGENT ECON. \& FIN. 1, 17 (2015).

${ }^{23}$ For the impact on the use of collateral in secured transactions, see INT'L. FIN. CORP., supra note 3, at 41-42.

${ }^{24}$ Charles W. Mooney, Jr., Insolvency Law as Credit Enhancement and Enforcement Mechanism: A Closer Look At Global Modernization of Secured Transactions Laws, 27 NORTON J. BANKR. L. \& PRAC. 673, text accompanying note 54 (2018).

${ }^{25}$ See Thorsten Beck et al., Bank Financing for SMEs around the World 7-8 (WBG, Pol'y Rsch. Working Paper No. 4785, 2008), http://documents.worldbank.org/curated/en/706131468159334938/pdf/WPS4785. pdf [https://perma.cc/2UPT-MGZA] (discussing banks' perception of government programs that support SMEs in both developed and developing countries).

${ }^{26}$ See Calice, supra note 8 (assessing implementation of the Principles for public credit guarantees for SMEs). 
guarantees in the world. ${ }^{27}$ Acknowledging the negative effect of this type of lending, Japan has undertaken efforts to modernize its secured transactions framework to provide a legal environment more conducive to market-based financing. ${ }^{28}$ The design of a guarantee scheme will inevitably affect the deployment of any reformed secured transactions framework in Japan, particularly to support asset-based lending that relies on inventory and receivables as collateral. ${ }^{29}$

Public guarantees have proven to be an effective countercyclical tool to address some negative consequences of extraordinary events, such as natural disasters or credit crises. ${ }^{30}$ Their role has also increased during the COVID-19 pandemic. However, during these extraordinary situations and states of emergency, the functions and features of public guarantees differ and do not apply generally when assessing their role in facilitating access to credit in economies.

\footnotetext{
${ }^{27}$ See infra Section IV(0).

${ }^{28}$ In relation to assignment of receivables, a new obligational law, enacted May 26, 2017, entered into force April 1, 2020. An informal project to reform the secured transaction law relating to movable assets (including receivables) is being spearheaded by the Ministry of Justice, called "Dousan Saiken wo Chushin toshita Tanpohousei ni Kansuru Kenkyukai" [Research Group on Security Interest Primarily in Movable Assets and Receivables], https://www.shojihomu.or.jp/kenkyuu/dou-tanpohousei [https://perma.cc/RQ74M8FZ] (last accessed Oct. 24, 2020). The Japan Business Credit Project (JBCP), an ongoing research project of Professor Megumi Hara, Gakushuin University School of Law, Professor Kumiko Koens, Yamagata University Faculty of Literature and Social Sciences, and Professor Charles W. Mooney, Jr., University of Pennsylvania Law School, involves an assessment of business credit and legal framework in Japan, including financing secured by personal property. It examines the reasons why such secured financing represents only a small portion of Japanese business credit and why Japan has not adopted modern principles of secured transactions law. Preliminary findings particularly relevant to this article are that the prevalence of government guarantees of bank loans to SMEs discourage the extension of such secured credit and impede the adoption of secured transactions law reforms. See also Mooney, supra note 24.

${ }^{29}$ See infra Section III(0).

${ }^{30}$ See Arito Ono \& Yukihiro Yasuda, Forgiveness Versus Financing: The Determinants and Impact of SME Debt Forbearance in Japan, 17 RsCH. INST. ECON., TRAdE \& IndUS. Discussion PAPER SERIES 1, 5 (2017), https://www.rieti.go.jp/jp/publications/dp/17e086.pdf [https://perma.cc/BY9YU2ZD] (stating that before the global financial crisis, $40 \%$ of Japanese SMEs had their loans guaranteed).
} 
This article explores the key roles of guarantee schemes and their effect on market-based financing. It finds ample evidence that the system of guaranteed lending has negative economic additionality. ${ }^{31}$ Guaranteed lending does not facilitate "valuecreation-orientated" financing, highlighted in a 2012 report by the Financial System Council of Japan. ${ }^{32}$ It stifles the growth of Japanese SMEs and the exit of zombie companies. Its magnitude and entrenchment is a significant hurdle to the development of marketbased financing. This article is organized as follows. After this Introduction, Section II examines various types of state interventions and their effect on access to credit. Section III describes the current lending conditions in Japan, including the type of credit available to SMEs and the secured transactions legal framework. Section IV traces the evolution of guarantee schemes, maps the various types, provides a detailed description of the Japanese Credit Supplementation System, and highlights the functions of guarantee schemes during crises, including the COVID-19 pandemic. Section $\mathrm{V}$ identifies various incentives for Japanese lenders and borrowers to utilize government-supported financing, and identifies distortions caused by the guarantee scheme. Section VI concludes.

\section{STATE INTERVENTIONS IN CREDIT MARKETS: ARE THEY INCENTIVIZING ACCESS TO CREDIT?}

Various state interventions seek to facilitate access to credit and contribute to the operation of a safe and sound financial system. These interventions may be general providing an enabling legal and regulatory environment, but also be specific affecting the allocation

\footnotetext{
${ }^{31}$ See Facundo Abraham \& Sergio L. Schmukler, Are Public Credit Guarantees Worth the Hype? (WGB, Rsch. \& Pol'y Brief No. 11, 2017), http://documents 1.worldbank.org/curated/en/431261511201811430/pdf/Arepublic-credit-guarantees-worth-the-hype.pdf [https://perma.cc/VF99-3SCK] (stating that economic additionality means improvement in the performance of borrowers); Calice, supra note 8. (arguing that measuring financial and economic additionality of credit guarantee schemes remains challenging).

32 Fin. Sys. Council, The Japanese Financial Industry: Desirable

State in the Medium and Long-Term (Present State and Future OUTLOOK) 14-15 (2012), https://www.fsa.go.jp/en/refer/councils/singie_kinyu/20120831/01.pdf [https://perma.cc/PP8T-82WM].
} 
of credit risk or the cost structure of a transaction. ${ }^{33}$ The specific measures include reducing capital requirements for selected types of loans, imposing lending requirements on financial institutions to dedicate a proportion of their loan book to a specific industry, providing credit guarantees to cover post-default losses, establishing and supporting state banks, or providing various refinancing facilities where financial institutions may obtain funds against self-liquidating instruments, such as loans secured with warehouse receipts. ${ }^{34}$ These interventions are generally designed to address a credit market failure that impairs access to credit. ${ }^{35}$

The existence of a market failure does not, on its own, provide the basis to institutionalize a particular state intervention from the menu of available options. ${ }^{36}$ In many cases, especially for public guarantees, they may distort the discipline of the competitive

${ }^{33}$ See Castellano \& Dubovec, Credit Creation, supra note 5, at 65-66.

${ }^{34}$ See DE LA TORRE ET AL., supra note 16, at 77 (listing state intervetion measures). See generally LEORA KLAPPER \& RIDA ZAIDI, A SURVEY OF GOVERNMENT REGULATION AND INTERVENTION IN FINANCIAL MARKETS 102 (2005) (discussing other types of state interventions); infra Section IV(0) (discussing other measures deployed during a crisis); Tatiana Didier et al., Financing Firms in Hibernation During the COVID-19 Pandemic 19 (WBG, Pol'y Rsch. Working Paper No. 9236, 2020),

https://openknowledge.worldbank.org/bitstream/handle/10986/33745/FinancingFirms-in-Hibernation-during-the-COVID-19-

Pandemic.pdf?sequence $=1 \&$ isAllowed $=y$ [https://perma.cc/FW2C-JC2U] (showing that authorizing the central bank to purchase portoflios of SME loans is an example of a measure deployed during a crisis).

35 Teresa Rodríguez de las Heras Ballell, Digital Technology-Based Solutions for Enhanced Effectiveness of Secured Transactions Law: The Road To Perfection?, 81 L. \& ConTEMP. PROBS. 21, 25-26 (2018).

${ }^{36}$ Joseph E. Stiglitz, The Role of the State in Financial Markets, in Proceedings of the World Bank Annual Conference on DeVelopment ECONOMIES 1993 19-20 (1994). 
market, ${ }^{37}$ and even disadvantage the most innovative businesses. ${ }^{38}$ Guarantee schemes firmly entrenched within a system may become a disincentive to institutionalizing an enabling legal and regulatory environment.

Various justifications have been provided for institutionalizing state interventions to address a particular market failure. The rationale for implementing directed lending programs may be to channel financing to increase industry production, especially where tariffs and subsidies are ineffective, ${ }^{39}$ or where specific projects would not otherwise be funded. ${ }^{40}$ A directed lending policy typically requires financial institutions to dedicate a certain percentage of their loan portfolio to a designated sector of the economy, such as exports, manufacturing, or agriculture, but without necessarily having to take any collateral. ${ }^{41}$ Other state interventions have been implemented to facilitate the development of a certain market followed by their gradual retraction when the market operates efficiently. Bankers' acceptances are one such measure utilized in the United States to provide short-term trade finance under the Federal Reserve Act of 1913. ${ }^{42}$ Acceptances issued to finance

${ }^{37}$ Robert C. Merton \& Zvi Bodie, On the Management of Financial Guarantees, 21 Fin. Mgmt. 87, 103 (1992). For Japan, see Chusho-kigyo Shoukibo-Jigyousha no Jigyou no Hatten wo Sasaeru Jizoku Kanouna Sinyouhokan Seiso no Kakuritu ni Mukete [Small \& Medium Enter. Pol'y Making Council Fin. Working Grp., Working Paper on Establishment of Credit Supplement System Fostering the Growth of SMEs, 2016], https://www.chusho.meti.go.jp/koukai/shingikai/kihonmondai/2016/161221kihon mondai2.pdf [https://perma.cc/A8QB-US6W] [hereinafter SME Credit Supplement System].

${ }^{38}$ Aaron Edlin, Overtaking, in THE AMERICAN ILLNESS: EsSAYS ON THE RULE OF LAW 475 (F.H. Buckley ed. 2013).

${ }^{39}$ See Dimitri Vittas \& Yoon Je Cho, Credit Policies: Lessons from Japan and Korea, 11 WORLD BANK RSCH. OBSERVER 277, 279 (1996) ("If firms lack access to credit, other industrial policy tools, such as tariffs and subsidies, that may rely on cost and profit incentives to increase production could prove ineffective.").

${ }^{40}$ Stiglitz, supra note 36 , at $19,30$.

${ }^{41}$ See KLAPPER \& ZAIDI, supra note 34 (stating that these programs have generated many inefficiencies, including the misuse of allocated credit, increase in the cost of finance for borrowers ineligible to benefit from the policy, and low repayment rates).

${ }^{42}$ Ralph T Helfrich, Trading in Bankers' Acceptances: A View from the Acceptance Desk of the Federal Reserve Bank of New York, FED. RSRV. BANK OF N.Y. MonThly REV., Feb. 1976, at 51. 
imports and exports, shipment and storage of goods were eligible for discount ${ }^{43}$ by a Reserve Bank if they met certain criteria. ${ }^{44}$ They have been gradually replaced by market-based financing products.

Credit market failures may become particularly acute in the aftermath of extraordinary events necessitating the deployment of state interventions to balance the countercyclical effects. The effectiveness of these interventions depends to a great extent on the magnitude of the crisis, its origins, and the overall level of nonperforming loans. ${ }^{45}$ However, the connection between the two applications is close, as an intervention established to bolster SME access to credit during a crisis may persist. Their perpetuation becomes problematic in that guarantee schemes designed to tackle countercyclical effects when such circumstances no longer exist transfer excessive credit risk to the public sector. ${ }^{46}$ The exponential use of guarantee schemes to tackle the economic effects of the COVID-19 pandemic presents a significant risk for market-based financing if the schemes are not rolled back efficiently supporting economic recovery.

Several state interventions have been deployed in Japan's recent history to stimulate access to credit. Many of them have already been discontinued due to their negligible or questionable economic impact. For instance, banker acceptances emerged as a financing tool post World War I to stimulate commodities trading. ${ }^{47}$

43 This means a Reserve Bank may rediscount them for accepting banks at the Federal Reserve's Discount Rate.

${ }^{44}$ Robert K. La Roche, Bankers Acceptances, 79 FED. RsRV. BANK OF RiCHMOND ECON. Q. 75, 78 (1993).

${ }^{45}$ Douglas W. Arner et al., Financial Stability, Resolution of Systemic Banking Crises and COVID-19: Toward an Appropriate Role for Public Support and Bailouts 4 (Univ. of H.K. Fac. of L. Rsch. Paper No. 2020/044, 2020), https://papers.ssrn.com/sol3/papers.cfm?abstract_id=3664523 [https://perma.cc/2WAJ-72YH].

${ }^{46}$ Lucia Cusmano, SME and Entrepreneurship Financing, The Role of Credit Guarantee Schemes and Mutual Guarantee Societies IN SupPorting FinANCE FOR SMALL AND MEDIUM-SizED ENTERPRISES 54 (OECD \& SME Entrepreneurship Papers, 2018), https:/www.oecdilibrary.org/economics/sme-and-entrepreneurship-financing_35b8fece-en [https://perma.cc/7XNS-XUZU].

${ }^{47}$ Katsufumi Kanaoka, Nihon ni Okeru Ginkouhikiuketegataseido no Sousetsu: 1919 (Taisho 8) 1927 (Showa 2) nen ni Okeru

Ginkouhikiuketegatasijou no Tenkai [Creation of Banker's Acceptance System in 
The Bank of Japan rediscounted eligible acceptances enhancing their use and attractiveness for banks. However, because the eligibility criteria were very strict, they were used less extensively than in the United States. Several attempts to reinvigorate the acceptance market in Japan failed. ${ }^{48}$ The Japanese government also designed and deployed directed lending schemes. ${ }^{49}$ These were used primarily to expand capacity and modernize the industry in the 1950s and 1960s. ${ }^{50}$ Notably, the borrowers that received such financial assistance increased investment, and within three years weaned themselves off directed lending and relied instead on market-based loans. ${ }^{51}$ At different time periods, directed lending did not improve the borrowers' profitability or investment prospects..$^{52}$ Over the decades, guarantee schemes have grown significantly and remained the dominant state intervention supporting access to credit for Japanese SMEs.

\section{SME LENDING IN JAPAN: CONDITIONS AND LAW}

This Section examines the lending environment in Japan, setting the stage for analyzing the role of guaranteed and secured lending. It acknowledges that the development of market-based financing presupposes the existence of an effectively secured transactions legal framework. Such frameworks have been constructed around a set of internationally recognized principles. While presently the Japanese legal framework fails to meet them, a

\footnotetext{
Japan: Development of Banker's Acceptance Market from 1919 to 1927], NINGENSHAKAKIKANKYOUKENKYU 39-86 (2007).

${ }^{48} I d$.

${ }^{49}$ See Iichiro Uesugi et al., The Effectiveness of Public Credit Guarantees in the Japanese Loan Market, 24 J. JPN. INT'L ECON. 457, 460 (2010) (discussing the credit guarantee system in Japan); Arito Ono et al., Are Lending Relationships Beneficial or Harmful for Public Credit Guarantees? Evidence from Japan's Emergency Credit Guarantee Program, 9 J. Fin. STABILITY 151, 152 (2013) (discussing public credit guarantees in Japan which include the credit guarantee system).

${ }^{50}$ Vittas \& Cho, supra note 39, at 277, 282.

${ }^{51}$ Vittas \& Cho, supra note 39, at 286.

52 See Masami Imai, Regulatory Responses to Banking Crisis: Lessons from Japan, 39 GLOB. Fin. J. 10, 14 (2019) (discussing the negative impact practices of regulatory capital arbitrage had imposed on Japanese economy as well as problems of Japanese government's regulatory policies).
} 
legal reform effort has already been undertaken to incorporate a number of those principles.

\section{Lending Conditions}

Japanese businesses have ample access to low-cost credit. In 2019 , credit to the private sector exceeded $174 \%$ of the Japanese GDP. ${ }^{53}$ Even though this percentage signifies a high maturity of the financial market, a significant proportion of SME credit has been supported by guarantee schemes. Interest rates on loans have been hovering around historically low levels, and lending is increasing annually at around $2 \% .{ }^{54}$ The Bank of Japan highlighted that profitability of lending continues to decline in this environment that increases competitive pressure on lenders to reduce the interest rate below the risk commensurate to the loan. ${ }^{55}$ This competitive environment also has the effect of reducing the use of credit guarantees because the applicable fees increase transactional costs. However, the credit risk of financial institutions increases as the loans are neither guaranteed nor collateralized.

Japanese businesses face numerous economic challenges, including shrinking domestic markets, declining sales, sluggish performance, and low competitiveness. ${ }^{56}$ These challenges have been compounded by guarantee schemes. The OECD concluded that guaranteed lending in Japan results in weak profitability, low productivity, and high leverage of SMEs. ${ }^{57}$ The Japan Productivity Center found that Japan ranks 21st among the OECD countries in labor productivity. ${ }^{58}$ The unsuitability of guaranteed lending was

${ }^{53}$ See Domestic Credit to Private Sector (\% of GDP)_Japan, THE WORLD BANK, https://data.worldbank.org/indicator/FS.AST.PRVT.GD.ZS?locations=JP [https://perma.cc/7LGJ-2BDX] (last accessed Oct. 22, 2020).

${ }^{54}$ BANK OF JAPAN, FinANCIAL SyStem RePort 1, 88 (Apr. 2019).

${ }^{55} \mathrm{Id}$. at 2.

${ }^{56}$ FIN. SYS. COUNCIL, supra note 32, at 14-15.

57 OECD, JAPAN: Boosting GROWTH AND WELL-BEING IN AN AGEING SocIETY 15 (2016). See Naoyuki Yoshino \& Farhad Taghizadeh-Hesary, Major Challenges Facing Small and Medium-Sized Enterprises in Asia and Solutions for Mitigating Them 7 (ADBI Working Paper Series No. 564, 2016) (stating that only $5 \%$ of Japanese SMEs invest in research and development, which is comparatively low).

${ }^{58}$ Roudouseisansei no kokusaihikaku [International Comparison on Labor Productivity], JAPAN PRODUCTIVITY CTR., https://www.jpc- 
confirmed in the Financial Sector Assessment Program Report of the IMF. 59

In the year of 2020, the number of bankruptcies in Japan reached 7,773, which is the lowest in fifty years. ${ }^{60}$ This is attributable primarily to the support of credit guarantees and other measures to prop up failing businesses during the COVID-19 pandemic. ${ }^{61}$ Liquidation is the dominant process. ${ }^{62}$ According to the 2020 World Bank's Doing Business Report for Japan, the recovery rate for secured creditors is among the highest in the world, an average of 92.1 cents on the dollar of the creditor claims, compared to the OECD average of 70.2. ${ }^{63}$ Insolvency thus does not pose a risk to secured creditors.

The asset structure of Japanese businesses is conducive to collateralized lending. According to Japan's Ministry of Finance, in 2018, local companies (excluding banks and insurance companies)

net.jp/research/assets/pdf/R2attached2.pdf [https://perma.cc/9PQJ-T2DD] (last accessed Oct. 24, 2020).

${ }^{59}$ IMF, JAPAN: FinANCIAL SECTOR ASSESSMENT PROGRAM: TECHNICAL Note-Long-Term Challenges For FInANCIAL InTERMEDiATION 55-57 (IMF Country Report No. 17/283, Sept. 2017). See also Keieisha-Hosho ni Kansuru Guideline Kenkyu-kai [Working Group on Guideline for Personal Guarantee Provided by Business Owners] (2014); Keieisha-Hosho ni Kansuru Guideline [Guideline for Personal Guarantee Provided by Business Owners] (2014); Keieisha-Hosho ni Kansuru Guideline Kenkyu-kai [Working Group on Guideline for Personal Guarantee Provided by Business Owners] (2014).

${ }^{60}$ Zenkoku Tousan Joukyou (2020 nendo Kamihanki), TOKYO SHOKO RscH. (TSR), https://www.tsr-net.co.jp/en/bankruptcy/2020.html [https://perma.cc/JXD3-E2WN] (last visited Nov. 3, 2020).

${ }^{61} \mathrm{Cf}$. Kimie Harada et al., Lessons from Japan's Shadow Financial Regulatory Committee Japan in the Global Financial Crisis, in WORLD IN CRISIS: INSIGHTS FROM SIX SHADOW FINANCIAL REGULATORY COMMITTEES FROM AROUND THE WORLD 193, 219 (Robert Lipton ed., 2011).

62 Out of 8,517 insolvency cases in 2015, liquidation accounted for $97 \%$. Randall Jones \& Yosuke Jin, Boosting Productivity for Inclusive Growth in Japan 13 (OECD Econ. Dep't Working Paper No. 1414, 2017).

${ }^{63}$ This impressive recovery rate reflects: (i) the average duration of insolvency proceedings at 0.6 years, compared to the 1.7 years OECD average; and (ii) the relatively low cost of insolvency proceedings at around $4.2 \%$ of the debtor's estate, compared to the OECD average of 9.3\%. WBG, Doing Business 2020: Japan 104-105 (2020), https://www.doingbusiness.org/content/dam/doingBusiness/country/j/japan/JPN.p df [https://perma.cc/N5J5-4WA8]. 
held receivables nearly equal in value to land. ${ }^{64}$ Moreover, the aggregate value of receivables and inventory was estimated to be valued at around 1.5 times that of land. ${ }^{65}$ Despite the value of personal property that Japanese SMEs own, its use as collateral has been negligible. ${ }^{66}$

Studies found that those Japanese borrowers that have longterm relationships with banks are more likely to provide collateral. ${ }^{67}$ While a typical Japanese SME has a long-term relationship with a single bank, it engages in transactions with multiple financial institutions. ${ }^{68}$ These multiple relationships are insurance for when one of those financial institutions experiences difficulties that result in retraction of lending. Given the common occurrence of borrowers having relationships with multiple financial institutions, the use of collateral is partially motivated by the desire of the financial institution to establish the priority of its claim over the other financial institutions with which the borrower transacts. ${ }^{69}$ Figure 1 presents the total number of loans extended to Japanese borrowers that have been secured with some asset.

\footnotetext{
${ }^{64}$ Ministry ECON., TRADE \& INDUS. (METI), Financial Statements Statistics of Corporations by Industry 2018, https://www.estat.go.jp/dbview?sid=0003060791 [https://perma.cc/L2HM-VECX] (last accessed Oct. 24, 2020).

${ }^{65}$ See Statistics of Japan, E-STAT, https://www.e-stat.go.jp/en [https://perma.cc/2GLB-BSS4] (last accessed Oct. 24, 2020).

${ }^{66}$ A study of a sample of 400,000 Japanese firms between 2007 and 2010 found that $51.9 \%$ mortgaged real estate, $23 \%$ did not provide any collateral, and $44.6 \%$ of firms obtained fully or partially guaranteed loans. Arito Ono et al., $A$ New Look at Bank-Firm Relationships and the Use of Collateral in Japan: Evidence from Teikoku Databank Data, in THE ECONOMICS OF INTERFIRM NETWORKS 204-205 (Tsutomu Watanabe et al. eds., 2015). This is at odds with FSB data which indicated that over the last decade, collateralization of loans has been reduced from over $90 \%$ of loans being secured with a right in an asset to less than $80 \%$. FSB, EVALUATION, supra note 10, at 13-14.

${ }^{67}$ Arito Ono \& Iichiro Uesugi, Role of Collateral and Personal Guarantees in Relationship Lending: Evidence from Japan's SME Loan Market, $41 \mathrm{~J}$. MONEY, CREDIT \& BANK. 935, 936 (2009).

${ }^{68} I d$., at 935,937 . It has been estimated that $80 \%$ of Japanese enterprises have relationships with multiple banks. Ono et al., supra note 66.

${ }^{69}$ Ono, supra note 67, at 951.
} 
Use of Asset-Based Lending (ABL) in Japan: Figure $1^{70}$

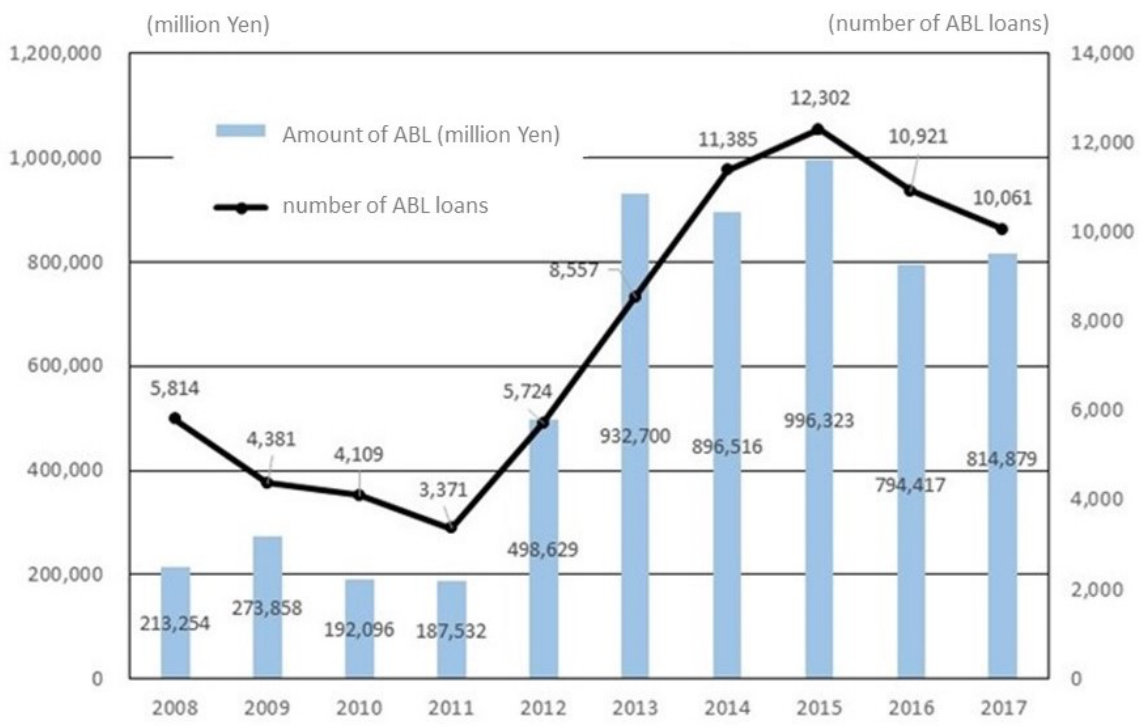

Banks are the primary driver of SME finance in Japan. When lending, banks rely on guarantees, and, to some extent, collateral, disregarding the overall business value. ${ }^{71}$ Fintech credit (estimated at 2.2 billion USD in 2019) in Japan is primarily extended in the form of $\mathrm{P} 2 \mathrm{P} /$ marketplace business and property lending. ${ }^{72}$ Although

${ }^{70}$ Teikoku Data Bank, Kigyou no Tayouna Sikinchoutatu Shuho ni Kansuru Jittai Houkokusho 2019nen 2 gatsu [Report on the current status of various corporate financing Feb 2019], MinISTRY ECON., TRADE \& INDUS. (METI) 5 (2019), https://www.meti.go.jp/policy/economy/keiei_innovation/sangyokinyu/itakuhouk oku/06.pdf [https://perma.cc/M5RV-WYCL].

${ }^{71}$ This practice leads to "Japanese version of lending exclusion." In contrast, some regional banks and credit unions challenge the traditional lending model fostering "lending inclusion" by deploying different lending methods. The FSA policies have contributed to this bipolarization in the lending market. See FinANCIAL SERVICes Agency (FSA), Summary Points from Strategic Directions and Priorities 2016-2017, https://www.fsa.go.jp/en/news/2016/201611301/01.pdf [https://perma.cc/4C92-7XTM] (last accessed Oct. 22, 2020); Takunori Hashimoto, The Bipolarization of the Regional Banks and Its Future "Problem Solving Type Banks" and "Lending Exclusion Type Banks," 14 J. JPN. SOC. INTELL. PROD. 14, 15 (2018).

${ }^{72}$ Giulio Cornelli et al, Fintech and Big Tech Credit: A New Database 8 (BIS, Working Paper No. 887, Sept. 2020). 
BigTech credit represents only a moderate share of overall credit, ${ }^{73}$ Japan is the second-largest market for BigTech credit (23.5 billion USD in 2019). ${ }^{74}$ Rakuten has offered a suite of financial products in Japan since 2013, including payments, lending, credit cards, mortgages and insurance. ${ }^{75}$ Social media company LINE offers consumer lending (through a joint venture with Mizuho Bank and a credit card company), telecommunication firm NTT DoCoMo provides customer credit-scoring services (under contractual agreement with banks and customers), and Amazon lends through its seller lending program. ${ }^{76}$ The second largest telecommunications provider, KDDI, has a joint venture with MUFG Bank called Au Jibun Bank. ${ }^{77}$

The use of collateralized lending presupposes the existence of a legal framework that is conducive to that type of lending. ${ }^{78}$ Such a legal framework enables an efficient use of personal property, such as inventory and receivables as collateral for a loan.

\section{Secured Transactions Frameworks: International Principles and Japan}

A modern secured transactions framework achieves several objectives if it sits on top of a solid foundation. ${ }^{79}$ First, it facilitates access to secured credit for businesses. ${ }^{80}$ Second, it fosters financial

${ }^{73}$ Jon Frost et al, BigTech and the Changing Structure of Financial Intermediation 11 (BIS, Working Paper No. 799, Apr. 2019).

${ }^{74}$ Cornelli et al, supra note 72 , at 8 .

${ }^{75} \mathrm{Id}$.

${ }^{76} \mathrm{Id}$.

${ }^{77} \mathrm{Id}$.

${ }^{78}$ In jurisdictions with outdated legal regimes, SMEs frequently cite insufficient or unacceptable collateral as the reason for not being able to access credit. See DE LA TORRE ET AL., supra note 16, at 5.

${ }^{79}$ See Eur. Bank ReCONSTRUCTION \& DeV. (EBRD), Secured Transactions, https://www.ebrd.com/what-we-do/legal-reform/access-tofinance/transactions.html [https://perma.cc/2XQQ-8EFY] (last accessed Nov. 1, 2020) (stating the Ten Core Principles published by the European Bank for Reconstruction and Development (EBRD) to supplement its 1994 Model Law on Secured Transactions and the United Nations Commission on International Trade Law (UNCITRAL) in its 2016 Model Law on Secured Transactions).

${ }^{80}$ In some economies with inefficient secured transactions frameworks, credit to the private sector may be around $30 \%$ of their gross domestic product (GDP). See IFC, supra note 3, at 5. 
inclusion by expanding finance in underserved segments of the economy. ${ }^{81}$ Finally, when coordinated with prudential regulatory standards, it reinforces financial stability and responsible lending. ${ }^{82}$ Such a solid foundation should be constructed from a set of principles. These principlescover all aspects of secured transactions, addressing risks, inefficiencies and frictions. They include: (i) comprehensive coverage of all forms of security interests in personal property (the functional approach); (ii) enabling the borrower to, efficiently and at a low cost, create a security interest without depriving it of the use of those assets; (iii) security interests available over all types of personal property, to secure all types of obligations, between all types of persons; (iv) effective means of publicizing the existence of security interests to third parties; (v) an electronic and notice-based registry that enables searches according to identifiers of persons who granted security interests; (vi) priority rules that enable access to credit from multiple creditors, including suppliers and lessors; (vii) predictable rules governing the competing rights of persons in the collateral, including non-consensual creditors; (viii) on default, the ability to promptly and efficiently enforce a security interest against the collateral to satisfy the secured obligation; (ix) predictable conflicts of laws rules that determine the law applicable to various aspects of the secured transaction; and ( $\mathrm{x}$ ) the protection of a security interest in insolvency. ${ }^{83}$

The Japanese secured transactions framework deviates from most of these principles. Foremost, it does not follow the functional approach that recognizes multiple security devices that may be used side by side without a coherent priority regime underpinned by an

\footnotetext{
${ }^{81}$ See generally INT'L FIN. CORP. (IFC), Financial Inclusion: Creating Opportunity through Financial, https://www.ifc.org/wps/wcm/connect/1116ecf69fdb-415f-ae2f304a8b9dc8d8/Financial+Inclusion.pdf?MOD=AJPERES\&CVID=kkIBXtL [https://perma.cc/JE46-8GNH] (last accessed Oct. 30, 2020).

${ }^{82}$ See Castellano \& Dubovec, Credit Creation, supra note 5; Castellano \& Dubovec, Global Regulatory Standards, supra note 5.

${ }^{83}$ See generally Charles W. Mooney, Jr., Lost in Transplantation? Modern Principles of Secured Transactions Law as Legal Transplants, in SECURED Transactions LaW in Asia: Principles, PERSPECtives AND REFORM (Louise Gullifer \& Dora Neo eds., 2020); MAREK DubOVEC \& Louise GulLifER, SECURED TRANSACTIONS LAW REFORM IN AFRICA 36-40 (2019).
} 
electronic registration system. ${ }^{84}$ The Civil Code recognizes the following four types of security interests (real rights) (i) pledge; (ii) hypothec; (iii) preferential rights (e.g., a right to the payment of wages); and (iv) rights of retention. Japanese SMEs also utilize trade credit, where the seller may retain ownership until payment of the purchase price in full while the buyer/debtor acquires possession and use of the asset. ${ }^{85}$ New types of security interests emerged through case law or were provided for in special statutes, such as for the financing of cars, agricultural products, construction machines, aircraft, ships, or the entirety of assets of particular types of businesses, such as railroad companies. ${ }^{86}$ As a consequence of these developments, the legal framework is fragmented.

Some security interests, such as the sale and leaseback or security transfer of ownership [joto-tanpo] emerged in response to the impracticality of the Civil Code. The impracticalities exist with respect to the failure to recognize a security interest over an asset in possession of a borrower that needs to use or sell it, the inefficiency of the enforcement provisions, as well as the need to more easily achieve priority over competing claims. ${ }^{87}$ The increasing growth in utilization of joto-tanpo in practice has been supported by a number of Supreme Court decisions. ${ }^{88}$ However, this device has practical limitations, including the inability to cover all assets that typically secure an asset-based loan, especially inventory, receivables, and proceeds, as well as the uncertainty stemming from the effect of registration. ${ }^{89}$ Unlike the United States, Japan has not established an

\footnotetext{
${ }^{84}$ For the explanation of the functional approach, see Hideki Kanda, Methodology for Harmonization and Modernization of Legal Rules on Secured Transactions: Legal, Functional, or Otherwise?, 22 UNIF. L. REV. 885, 885-886 (2017).

${ }^{85}$ Daisuke Tsuruta, How Do Small Businesses Finance Their Growth Opportunities? - The Case of Recovery from the Lost Decade in Japan, 33 MANAGERIAL \& DECISION ECON. 189, 191 (2012).

${ }^{86}$ Hiroto Dogauchi \& TANPo BuKkEN Hou, Security InTEREST LaW (4th ed., 2017); Megumi Hara, Japan, in SECUREd Transactions LaW IN Asia: PRINCIPLES, PERSPECTIVES, AND REFORM (Louise Gullifer and Dora Neo eds., 2020).

${ }^{87}$ Id. at 6-7. See also Hisakazu Matsuoka \& TANPO BuKKEN Hou, SECURITY INTEREST LAW 208-311 (Nihonhyoronsha, 2017); HIROSHI ODA, JAPANESE LAW 166, 177 (3d ed., 2009).

${ }^{88}$ See, e.g., Hanrei Jihou Sept. 28, 1982 [1981(O) No. 1209] No. 1062, 81.

${ }^{89}$ Hara, supra note 86.
} 
equivalent to the UCC Article 9 filing system. In such a legal environment, it is challenging for Japanese lenders, when they extend market-based or guaranteed loans, to reliably take a security interest in some collateral.

Recent reforms to facilitate the financing of receivables by limiting the effect of anti-assignment clauses are a step forward. However, they fall short of aligning the Japanese framework with the international principles. ${ }^{90}$ Given the many departures of the Japanese secured transactions framework from the modern principles, steering lenders toward asset-based lending may present legal risks that would make the cost of such credit uneconomical and unattractive as compared to guaranteed loans. The abundance of low-cost guaranteed credit affects the incentives to consider reform of the Japanese secured transactions framework to align closely with the international principles. ${ }^{91}$

${ }^{90} I d$.

91 The design of a secured transactions reform in Japan and the effect of public guarantees is being explored by the Japan Business Credit Project. The Secured Transactions Law Reform in Japan: Globally and in Japan Conference, co-organized by The Bank of Japan, Gakushuin University, Nishimura \& Asahi, and University of Pennsylvania Law School, held July 30-31, 2018 in Tokyo, recognized and discussed the connection between public guarantee schemes and secured lending in Japan. Those discussions also influenced the focus of this article. The Japan Business Credit Project (JBCP) is a research project of Professor Megumi Hara, Gakushuin University School of Law, Professor Kumiko Koens, Yamagata University Faculty of Literature and Social Sciences, and Professor Charles W. Mooney, Jr., University of Pennsylvania Law School. The JBCP has undertaken more than 30 semi-structured interviews of bankers, legal practitioners, academics, and government officials. The project involves an assessment of business credit in Japan, including financing secured by movables and receivables and the relevant legal framework. It includes an examination of the reasons why such secured financing represents only a small portion of Japanese business credit and why Japan has not adopted modern principles of secured transactions law. Preliminary findings particularly relevant to this paper are that the prevalence of government guarantees of bank loans to SMEs discourage the extension of such secured credit and impede the adoption of secured transactions law reforms. See Charles W. Mooney, Jr., Insolvency Law as Credit Enhancement and Enforcement Mechanism: A Closer Look at Global Modernization of Secured Transactions Laws, 27 NORTON J. BANKR. L. \& PRAC. 673 (2018); Mooney, supra note 83; 83Hara, supra note 86. 


\section{CRedit Guarantee Schemes: Evolution, Governing PrinciPles, TYPES, AND THE JAPANESE STRUCTURE}

\section{Evolution}

From their emergence in nineteenth century Europe, guarantee schemes proliferated in the last decades. ${ }^{92}$ Particularly in some OECD countries, they have become the policy of choice for supporting SME credit. ${ }^{93}$ The reasons for their establishment vary and also depend on the state of the financial market. In economies with developing financial markets that do not efficiently distribute risks, guarantee schemes have played a transitory role providing a bridge to market-based financing. ${ }^{94}$

Guarantee schemes in Japan have a long history, operating at the level of prefectures with support from a central governmental agency. In 1948, the Japanese government established the Small and Medium Enterprise Agency, which led the process of forming prefectural credit guarantee corporations (CGCs). ${ }^{95}$ The Credit Guarantee Law No. 196 of 1953 governs the establishment, administration, and operations of CGCs that are subject to the supervision of the Ministry of Economy, Trade and Industry (METI), the Financial Services Agency (FSA), as well as local authorities in the prefectures where they operate.

\footnotetext{
92 OCED, FACILITATING ACCESS TO FINANCE: DisCUSSION PAPER ON CREdit GuARANTEE SCHEMES 3 (2010), https://www.oecd.org/globalrelations/45324327.pdf [https://perma.cc/L8R22E3B].

${ }^{93}$ See also Uesugi, supra note 49, at 458; Moustafa Chatzouz et al., Credit Guarantee Schemes for SME Lending in Western Europe 10 (Eur. Inv. Fund (EIB), Working Paper No. 2017/42, June 2017), http://www.eif.org/news_centre/publications/eif_wp_42.pdf [https://perma.cc/CR46-3CST].

${ }^{94}$ Deniz Anginer et al., Risk-Bearing by the State: When Is It Good Public Policy?, J. Fin. STABILITY 76 (2013), https://openknowledge.worldbank.org/handle/10986/13732?show=full [https://perma.cc/8583-NMGN]. The inefficient distribution of risks is largely attributable to the lenders' lack the expertise in extending and administering loans secured with personal property.

${ }^{95}$ Uesugi, supra note 49 , at 460-61.
} 
Since 1951, the government has insured guarantees issued by the prefectural CGCs. ${ }^{96}$ Today, the insurance is provided by the Japan Finance Corporation (JFC). The JFC's role is to (i) provide a safety net to respond to risks from unexpected circumstances ${ }^{97}$ such as natural disasters; (ii) support start-ups; and (iii) facilitate revitalization and foreign expansion of businesses. ${ }^{98}$ JFC also extends loans directly to businesses. ${ }^{99}$ As of March 2019, JFC's loans to SMEs represented $4.2 \%$ of all SME loans in the economy. JFC disbursed loans to 0.88 million microenterprises, about half of which were sole proprietors ${ }^{100}-86.7 \%$ of these loans were not supported by any collateral. ${ }^{101}$ The JFC and the CGCs form the Credit Supplementation System. ${ }^{102}$

${ }^{96}$ In 1958, the insurance function was transferred from the government to the Small Business Credit Insurance Corporation. Atsuo Kuroda, Credit Supplementation System for Unlocking SME and Startup Access to Finance, The Case of Japan, in UNLOCKING SME FINANCE IN ASIA, ROLES OF CREDIT RATING AND CREDIT GuaranteE Schemes 247 (Naoyuki Yoshino \& Farhad TaghizadehHesary eds., 2019).

97 The Ministry of Economy, Trade and Industry decided to activate the safety net guarantee for the companies suffering from declining sales due to the coronavirus (COVID-19) pandemic and to widen the types of beneficiaries covered by the safety net guarantee. See Ministry ECON., TradE \& InDUS. (METI), Measure for Supporting SME's Affected by Novel Coronavirus to be Taken (Designation of Areas Subject to No. 4 Safety Nets for Financing Guarantee) (Feb. 28, 2020), https://www.meti.go.jp/press/2019/02/20200228001/20200228001.html [https://perma.cc/D9H9-V7UW]; see also MINISTRY ECON., TRADE \& INDUS. (METI), We Will Take Measures for Small and Medium-Sized Enterprises Related to the New Coronavirus Infection (Mar. 3, 2020), https://www.meti.go.jp/press/2019/03/20200303002/20200303002.html [https://perma.cc/WV4R-KU85].

98 JAPAN FIN. CORP. (JFC) 2018 Japan Finance Corporation Annual Report 6 (2018), https://www.jfc.go.jp/n/english/pdf/jfc2018e_1.pdf [https://perma.cc/57FV-5KVW].

${ }^{99}$ In contrast, the SBA pulled back from making direct loans in the mid1980s acknowledging that the private market is more efficient in deciding which loans should be extended. See Craig et al., supra note 1, at 350.

100 JFC 2019 Japan Finance Corporation Annual Report (2019), https://www.jfc.go.jp/n/english/pdf/jfc2019e_3.pdf. See also JFC, supra note 98.

101 JFC 2019, supra note 100.

102 See JFC, supra note 98 , at 52. 
Figure 2: The Credit Supplementation System ${ }^{103}$

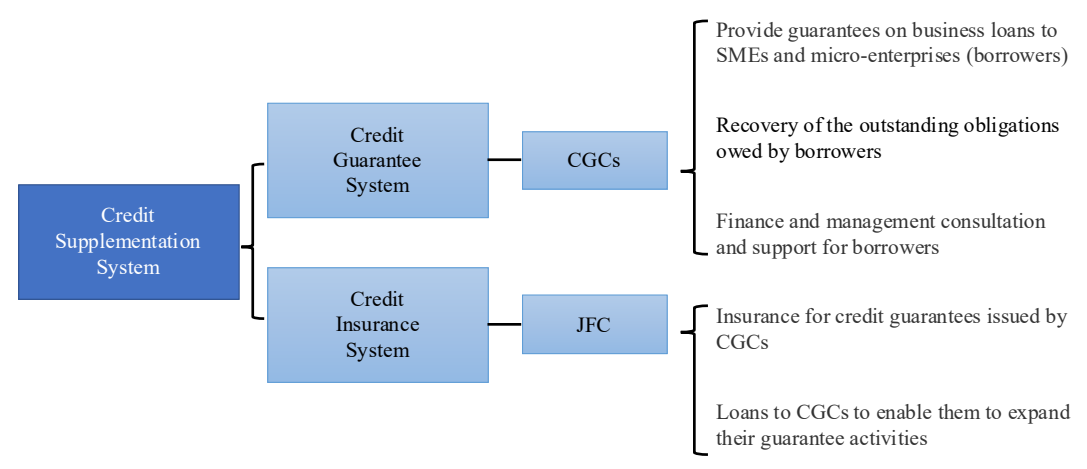

Since its inception, the beneficiaries of the Credit Supplementation System have expanded. New economic sectors have been added, and the caps on borrower size and guarantee limits have increased. ${ }^{104}$ Only certain types of SMEs, operating in the agriculture, forestry, fishery, or finance sectors remain ineligible. ${ }^{105}$

\section{International Perspectives}

Many guarantee schemes were set up decades ago, during which their effect on access to credit has grown. Globally, Japan and Korea are the leaders in the use of credit guarantees. Guaranteed loans represent a large share of their GDP-7.3\% in Japan and $6.2 \%$ in Korea in 2011. ${ }^{106}$ By contrast, credit guarantees represent only $0.4 \%$

103 JAPAN FED’N CREDIT GuAR. CORPS., Credit Guarantee System In Japan 20205 (2020), https://www.zenshinhoren.or.jp/document/Credit_Guarantee_System_in_Japan_2 020.pdf [https://perma.cc/D3TV-RVEC] (last accessed Apr. 17, 2021).

${ }^{104}$ Credit Guar. Corp. Tokyo, Annual Report 2019 3, 5 (2019), https://www.cgc-tokyo.or.jp/about/public/annualreport2019.pdf [https://perma.cc/7FXQ-KTWJ].

${ }^{105}$ The ineligible economic sectors are set out in in the enforcement regulation under the Small and Medium-Sized Enterprise Credit Insurance Act. See JFC, supra note 98, at 7.

${ }^{106}$ CUSMANO, supra note 46, at 11. 
of GDP in the United States, and less than $0.1 \%$ of GDP in Canada. ${ }^{107}$ The global median was $0.11 \%$ of GDP in $2014 .{ }^{108}$ On average, one third of Japanese SMEs obtain loans guaranteed through the Credit Supplementation System. ${ }^{109}$ Globally, the proportion of a country's SMEs with a loan covered by a credit guarantee averages less than $2 \% .{ }^{110}$ The percentage of Japanese SMEs that obtain guaranteed loans is even higher in some areas. ${ }^{11}$ For instance, the Tokyo CGC guarantees loans to $42.6 \%$ SMEs operating in the Tokyo Metropolitan Area, $74.2 \%$ of which have fewer than five employees. ${ }^{112}$

A set of globally recognized principles have been promulgated to guide the establishment and operation of guarantee schemes. The overarching objective of these principles is to ensure financial sustainability of schemes, for their administrators to apply proper risk mitigation mechanisms, and the fee structure to reflect the riskiness of the loan applicant. In 2015, the World Bank published Principles for Public Credit Guarantee Schemes for SMEs, which cover four aspects: (i) legal and regulatory framework; (ii) corporate governance; (iii) operational framework; and (iv) monitoring and evaluation. ${ }^{113}$

The first area covers the Principles relevant to this article. Principle 8 recommends that schemes implement an effective and comprehensive risk management framework that identifies risks related to its operation, and use credit risk mitigation techniques, such as counter-guarantees (insurance). Principle 11 recommends that schemes provide partial coverage of losses upon default, and that the

${ }^{107}$ Id. at 12, 46; Federal Reserve Bank of St. Louis Economic Data (FRED), Gross Domestic Product for Canada, FED. RES. BANK ST. LouIs (July 2, 2020), https://fred.stlouisfed.org/series/MKTGDPCAA646NWDB [https://perma.cc/2FXC-Q844].

108 Abraham \& Schmukler, supra note 31.

109 See Colacelli \& Hong, supra note 9, at 51; Kuroda, supra note 96, at 247.

${ }^{110}$ Abraham \& Schmukler, supra note 31.

$111 \mathrm{Id}$. at 51.

112 Credit Guar. Corp. ToKyo, supra note 104, at $11-12$. Over $90 \%$ of loans guaranteed by the Tokyo CGC are used to cover operating expenses.

113 See WBG, Priciples for Public Credit Guarantee Schemes (CGSs) for SMEs, https:/www.worldbank.org/en/topic/financialsector/publication/principlesfor-public-credit-guarantee-schemes-cgss-for-smes [https://perma.cc/BMT4HY72] (last accessed Oct. 22, 2020). 
guarantee should be designed to comply with capital requirements for credit risk. The coverage ratio should exceed $50 \%$ as any lower coverage might not be a sufficient incentive for lenders to extend credit. ${ }^{114}$ The Principles recommend that the fee reflect the riskiness of the particular guarantee, and should be adjustable to ensure financial sustainability of the scheme. ${ }^{115}$

Most of the schemes were established prior to the adoption of the Principles. Over the decades, their types, structures, and risk formulae have been shaped by various factors. As a result, there is no universally recognized structure or product that they offer.

\section{Types of Credit Guarantee Schemes}

Guarantee schemes may be categorized based on different features of the products they offer. Guarantees may be (i) available for portfolios or individual loans; (ii) wholly unsecured or require creditors to take collateral; (iii) covering a percentage of the outstanding amount (80-100\%) or the actual loss after enforcement upon default, known as second-loss guarantees. Credit guarantees may cover loans for working capital as well as investment. ${ }^{116}$

Different factors affect the design of a guarantee scheme. For instance, individual guarantees are used when the staff of the financial institution have particular expertise in assessing various risks, while a different risk management approach is necessary to guarantee portfolios. ${ }^{117}$ The individual approach is more appropriate for larger loans, while the portfolio approach is more cost-efficient for smaller loans or loans given to particular types of SMEs. ${ }^{118}$

The entities that issue guarantees may be: (i) public; (ii) public-private; or (iii) private. The first type is an important policy

${ }^{114} I d$. at 20.

${ }^{115} \mathrm{Id}$. at 38 .

${ }^{116}$ Guarantees for leasing, trade finance, and supply chain finance products are provided as well. For instance, Japan Bank for International Cooperation (JBIC) provides export and import loans as well as guarantees to businesses, including SMEs. See OCED, supra note 92, at 25.

117 Thorsten Beck et al., The Typology of Partial Credit Guarantee Funds Around the World 6 (WBG, Dev. \& Pol'y Rsch. Group Working Paper No. 4771, 2008), http://documents.worldbank.org/curated/en/937071468314370786/Thetypology-of-partial-credit-guarantee-funds-around-the-world [https://perma.cc/FB4W-YC9R].

${ }^{118}$ WBG, supra note 113 , at 36. 
tool of a government, and it is the main focus of this article. ${ }^{119}$ Guarantee schemes can be administered by: (i) international organizations; (ii) governments; (iii) corporations; or (iv) mutual guarantee associations. The United States Agency for International Development (USAID) Development Credit Authority's partial credit guarantees are an example of an international scheme that aims to promote lending in underserved markets. ${ }^{120}$ International schemes are often accompanied by technical assistance to upgrade the participating lenders' credit origination and risk management skills. ${ }^{121}$ Corporate schemes are funded and operated by the private sector, such as banks and chambers of commerce. Lastly, mutual guarantee associations are private sector schemes formed and managed by borrowers who contribute to a common fund that guarantees the repayment of a loan given to a member of the association.

The risk sharing formulae also differ. In one type of arrangement, the guarantor shares the losses pari passu with the lender or its right to recovery may be wholly subordinated to the lender. ${ }^{122}$ These formulae may be affected by regulatory aspects, such as the rules to prevent state aid within the European Union that requires losses to be sustained proportionally between the scheme operator and participating lenders. ${ }^{123}$ Schemes employ lossmitigation tools, such as counter-guarantees. If these counterguarantees or insurance are provided by governmental institutions, that may enhance the credibility and reputation of the scheme. ${ }^{124}$

\footnotetext{
119 Cusmano, supra note 46, at 16.

${ }^{120}$ U.S. Agency InT'L Dev., Development Credit Authority: Putting Local Wealth to Work, https:/www.usaid.gov/sites/default/files/documents/1865/DCA_One-

Pager_Financial_Partner.pdf [https://perma.cc/HB8M-LRLA] (last accessed Oct. 22, 2020).

${ }^{121}$ Calice, supra note 8.

122 OECD, supra note 92, at 13.

${ }^{123}$ See Commission Notice on the Application of Articles 87 and 88 of the EC Treaty to State Aid in the Form of Guarantees 155/02), O.J., June 20, 2008, at C155/10, https://eurlex.europa.eu/LexUriServ/LexUriServ.do?uri=OJ:C:2008:155:0010:0022:en:PDF [https://perma.cc/TPD9-2PJM] [hereinafter Commission Notice] ("First-loss guarantees, where losses are first attributed to the guarantor and only then to the lender, will be regarded as possibly involving aid.")

${ }^{124}$ Cusmano, supra note 46 , at 8.
} 
Some schemes are designed to operate specifically in conjunction with loans secured by personal property collateral. For instance, the World Bank Group supports the Second Loss Partial Credit Guarantee program, which is a structure that covers the risk of lenders that the proceeds from enforcement of a security interest will not suffice to fully satisfy the secured obligation. ${ }^{125}$ This may occur because the borrower obstructed the enforcement process or illiquid secondary markets preclude the sale of the collateral for a reasonable price. This structure incentivizes the lender to develop expertise in valuing, monitoring, and liquidating the collateral because it may claim payment on the guarantee only when the enforcement process was frustrated or the collateral sold for value less than the estimated liquidation value at the time of origination. ${ }^{126}$ However, this guarantee scheme structure has some downsides. Foremost, covering losses caused by an inefficient enforcement framework may become a disincentive to the government to seriously consider reforming that framework to expedite enforcement of security interests.

Guarantee schemes in many developed economies are almost fully funded by fees and recoveries of collateral on defaulted loans. ${ }^{127}$ Between 2016 and 2019, the United States Small Business Administration (SBA) did not require any government funding to subsidize the cost of its loan guaranty programs. ${ }^{128}$ Even the largest of these subsidies amounts to less than one thousandth of one percent of U.S. GDP. ${ }^{129}$ Similarly, in Canada, even the largest shortfalls of the Canada Small Business Financing Program, which offers 85\% credit guarantees on SME loans, amounted to only three thousandth

\footnotetext{
125 See also Second Loss Partial Credit Guarantee: Unlocking the Potential of Small and Medium Enterprises with an Innovative, Risk-Sharing Financing Solution, WBG, http://pubdocs.worldbank.org/en/362121537458541440/SLPCGBrochure-Jun11-hi-res.pdf [https://perma.cc/DW5N-XZ5G] (last accessed Oct. 22, 2020).

${ }^{126} \mathrm{Id}$.

127 Cong. Rsch. Serv., R41146, SMall Business Administration 7(A) LOAN GUARANTY PROGRAM 21 (2021), https://fas.org/sgp/crs/misc/R41146.pdf [https://perma.cc/59C7-TPCB].

${ }^{128}$ Id. From 2010 to 2015 , the SBA received annual subsidies of between $\$ 45$ million and $\$ 316$ million.

${ }^{129} I d$. In 2013, the SBA received \$316.3 million in total subsidies for its loan guaranty programs. The US GDP in 2013 was $\$ 16.69$ trillion. See United States, WORLD BANK DATA, https://data.worldbank.org/country/US [https://perma.cc/ZVW9-STRD] (last accessed Oct. 22, 2020).
} 
of one percent of its GDP. ${ }^{130}$ Although the schemes are usually subsidized from public resources, only a few disclose their financial data transparently. ${ }^{131}$

The optimal credit guarantee fee should be sensitive to macroeconomic fluctuations as well as to loan applicants' creditworthiness. ${ }^{132}$ To incentivize SMEs to improve their financial health and to avoid moral hazard, the fee should be commensurate to the SME risk profile. ${ }^{133}$ To promote borrowing during a recession or crisis, the fee should decrease to accommodate SMEs' lower output levels and higher default risk ratio. ${ }^{134}$ During an economic boom, complementary to contractionary monetary policy, the fee should increase to reduce demand and discourage aggressive lending to prevent the creation of a bubble. ${ }^{135}$

\section{Regulatory Treatment of Guaranteed Loans}

Regulatory treatment of loans is an important consideration for lenders, including when deciding on the type of security to to mitigate risks. Loans guaranteed by a qualified scheme may provide a regulatory benefit that may not be available for loans that are unsecured or secured with some collateral. This benefit may thus provide an economic incentive to utilize a particular credit risk mitigant. A survey of European banks found that one of the reasons for the use of public guarantees is capital relief since the portion of the loan covered by a guarantee may be subject to a lower risk weight. ${ }^{136}$ Another study on the impact of public guarantees in Western Europe revealed that about half of the banks that the study

\footnotetext{
${ }^{130}$ See Canada GDP, TRADING ECON., https://tradingeconomics.com/canada/gdp [https://perma.cc/C9JX-LCJB] (last accessed Oct. 22, 2020) (stating that the shortfall peaked at CAD 48.6 million in FY 2008-09). The Canadian GDP in 2009 was $\$ 1.37$ trillion.

${ }^{131}$ Farhad Taghizadeh-Hesary et al., A Model For Calculating The Optimal Credit Guarantee Fee for Small and Medium-Sized Enterprises (Asian Dev. Bank Inst., Working Paper No. 1045, Nov. 2019), https://www.adb.org/sites/default/files/publication/541041/adbi-wp1045.pdf [https://perma.cc/2PXT-2K3K].

${ }^{132} \mathrm{Id}$. at 2.

${ }^{133} \mathrm{Id}$.

${ }^{134} \mathrm{Id}$. at $2-3$.

${ }^{135} \mathrm{Id}$. at 2 .

${ }^{136}$ Chatzouz et al., supra note 93, at 33.
} 
covered reported that capital relief provided by guarantees is an important consideration for their use. ${ }^{137}$

Depending on how the Basel Accords are domestically implemented, guarantees may reduce risk weights. ${ }^{138}$ Some guarantees may benefit from regulatory relief only if the payment does not require the lender first having to pursue the borrower. Thus, this benefit would not accrue if the guarantee were designed as a second loss guarantee requiring the lender to first pursue the borrower and only then claim a payment for any outstanding losses.

In Japan, two separate capital requirements regimes apply based on the type of financial institution: (i) the international (Basel Accord) standard applies to banks with overseas branches; and (ii) the domestic standard applies to other banks. ${ }^{139}$ Though they differ in some ways, they share the same methods in the calculation of the capital relief. Of sixty-four regional banks, fourty-five use the standardized approach to calculate capital charges, as do thirty-eight of fourty second regional banks. ${ }^{140}$ These two types of banks utilize around half of all CGC guarantees as shown in the following figures.

${ }^{137} I d$. at 5 .

${ }^{138}$ A reduction may be available whether the financial institution utilizes the standardized or internal-ratings based approach. Id. at 34 .

139 JFSA Notification No. 19 of 2006 (Ginkouhou Dai14jouno2 no Kiteini Motoduki, Ginkouga Sono Hoyuusuru Sisantou ni Terashi Jikosihon no Juujituno Joukyouga Tekisetu dearukadouka wo Handansurutameno Kijun), https://www.fsa.go.jp/policy/basel_ii/ginkou1-01.pdf [https://perma.cc/ZB83XXB8] (last accessed Nov. 3, 2020) (Japan).

${ }^{140}$ About Regional Banks: Outline of Regional Banks, REG'L BANKS Ass'N JAPAN, https://www.chiginkyo.or.jp/app/contents.php?category_id=17 [https://perma.cc/6HW3-2U2W] (last accessed Oct. 22, 2020); English TOP, 2ND Ass'N REG'L BANKS, https://www.dainichiginkyo.or.jp/en.html [https://perma.cc/W3E3-H642] (last accessed Oct. 22, 2020). 
Figure 3: Number of Banks Using Standardized Approach

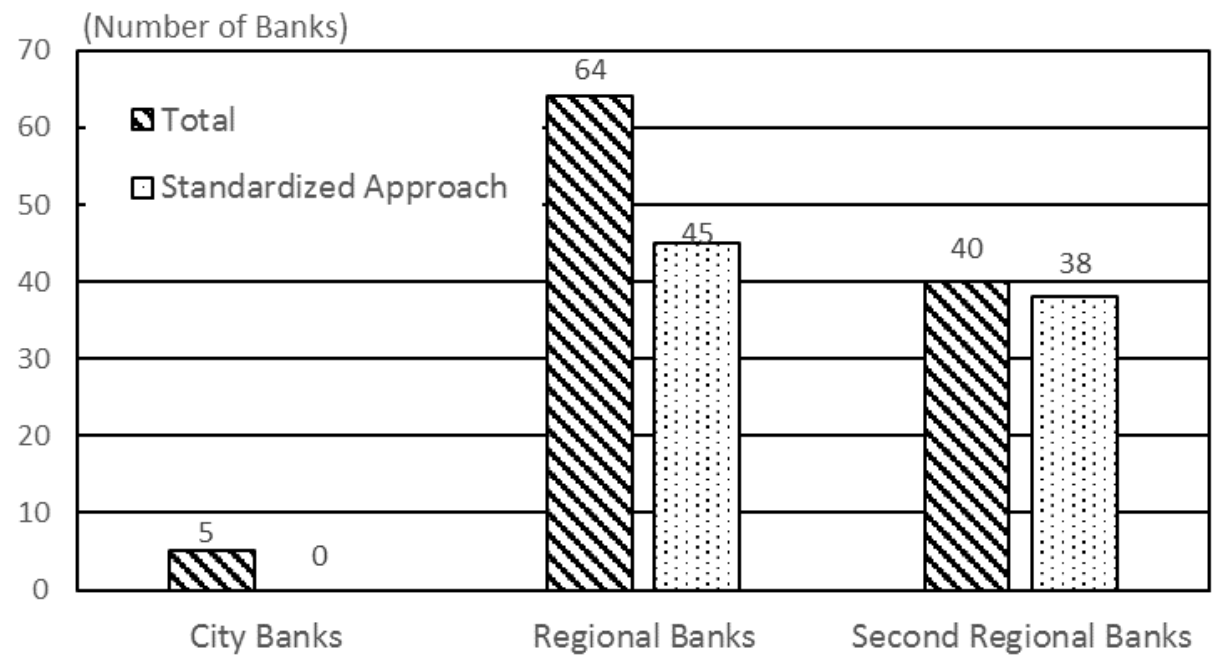

Figure 4: Use of Credit Guarantees According to the Type of the Bank

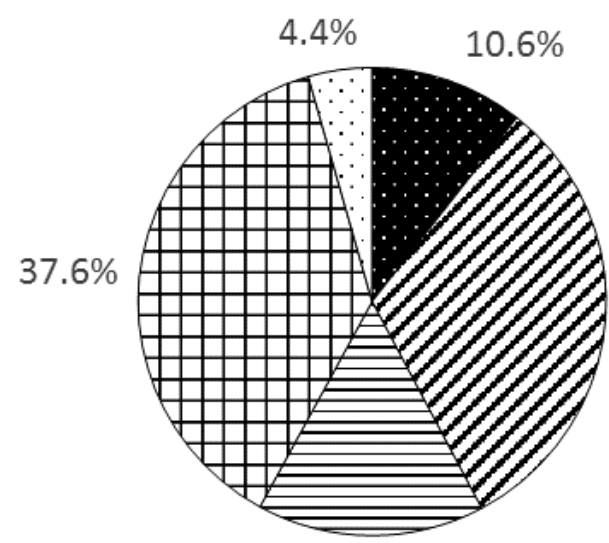

$15.7 \%$

- City Banks

$\boxminus$ Second Regional Banks

जothers
$31.6 \%$

Regional Banks

$\square$ Sinkin Banks 
Along with credit derivatives, ${ }^{141}$ depending on the nature of the issuer and their terms, guarantees may qualify as unfunded credit protection. ${ }^{142}$ For a scheme funded by a government with a AAA rating, the risk weight may be reduced to zero. ${ }^{143}$ After announcing and supporting the measures to encourage SME loan restructuring, in December of 2008, the risk weight of the guaranteed amount of the loan was reduced to zero. ${ }^{144}$ During the COVID-19 pandemic, banks can assign zero risk weights to loans covered by public guarantee schemes and draw down their high-quality liquid assets below the minimum liquidity coverage ratio requirement.

Principle 11 of the World Bank Group Principles for Public Credit Guarantee Schemes for SMEs recommends that "The guarantees should be ... designed to ensure compliance with the relevant prudential requirements for lenders, in particular with capital requirements for credit risk." The World Bank further explains that credit guarantees should be designed to meet the parameters prescribed by the Basel Accords to provide capital relief corresponding to the proportion of the credit exposure covered by the guarantee as well as to comply with the provisioning rules. ${ }^{145}$ Depending on the implementation of the Basel Accords, the structure of the guarantee may thus influence the capital treatment of the guaranteed loan, which in turn could be an incentive or a disincentive for regulated financial institutions to utilize a particular type of guarantee. Requiring some collateral as a condition of issuing a guarantee should enhance the recovery rate of the loan without any negative impact on the capital relief benefit.

After the adoption of the 2009 SME Financing Facilitation Act, Japanese financial institutions could exclude restructured SME loans from non-performing loans. ${ }^{146}$ This option is available if the 85.

${ }^{141}$ See also Castellano \& Dubovec, Bridging the Gap, supra note 5, at 63-

${ }^{142}$ Chatzouz et al., supra note 93, at 33-34.

${ }^{143}$ Cusmano, supra note 46, at 28.

${ }^{144}$ See Harada et al., supra note 61, at 218-219. Under the Emergency Credit Guarantee Program, introduced to ameliorate the effect of the credit crisis in October 2008, the risk weight of the guaranteed loans was reduced from $10 \%$ to 0 . See Ono et al., supra note 49, at 153.

${ }^{145}$ See WBG, supra note 113, at 21.

146 The FSA's Supervisory Guidelines were modified to the same effect. Nobuyoshi Yamori, The Effects of the Financing of the Financial Facilitation Act After the Global Financial Crisis: Has the Easing of Repayment Conditions 
financial institution expects the loans to perform within five years. Even though the Act ceased to have effect in March 2013, financial institutions have continued to grant requests for restructuring of loans, accepting 95\% of applications. ${ }^{147}$ The Act, and the practice it fostered, was criticized as the Japanese government using its discretion to soften prudential regulation that sustains zombie companies. ${ }^{148}$ This policy benefited financially weak financial institutions and their borrowers that would otherwise have been liquidated. ${ }^{149}$

\section{Operational Structure of the Japanese Credit Supplementation System}

The Japanese Credit Supplementation System has a twotiered structure that includes the JFC and prefectural CGCs. This structure is composed of a web of contractual relationships. Prefectural CGCs enter into blanket agreements with financial institutions that govern the general parameters of those relationships for any future lending activities. The Federation of CGCs issues a template, which may be modified by the prefectural CGCs, although that has not been common. For a guaranteed loan, the financial institution and the CGCs enter into a contract specific to that loan. Naturally, the financial institution and the borrower enter into a separate loan agreement. Finally, the CGC enters into an agreement with the borrower.

There are two ways in which an application for a guarantee may be generated: (i) by the prospective borrower who applies directly with the CGCs, or (ii) by the financial institution on behalf of the prospective borrower. ${ }^{150}$ The following is the usual process from the application for a guarantee to its satisfaction:

Revived Underperforming Firms?, J. Risk FIN. MGMT. 3-4 (2019); Kimie Harada et al., Japan's Financial Regulatory Responses to the Global Financial Crisis, 7 J. FIN. ECON. POL'Y 51, 62 (2015).

147 Yamori, supra note 146, at 4.

${ }^{148} I d$. at 5.

149 See Imai, supra note 52, at 11.

${ }^{150}$ Ono et al., supra note 49, at 152. 


\begin{tabular}{|l} 
(1) SME (borrower) applies for a credit guarantee from the \\
CGC directly or indirectly through a financial institution \\
(lender). \\
(2) approved (the CGC assesses the SME's \\
creditworthiness), SME and CGC enter into an agreement. \\
Upon satisfactory completion of its due diligence, the \\
lender enters into a contract and extends a loan to the SME. \\
CGC and the financial institution enter into a contract \\
related to the specific loan (the two already entered into an \\
umbrella agreement). \\
(5) CGC obtains insurance for the guarantee from the Japan \\
Finance Corporation (JFC) under a blanket contract \\
previously entered into. \\
(6) SME pays the guarantee fee to CGC. \\
(7) CGC pays the insurance premium to JFC. \\
(8) SME \\
(8a) repays the loan and the transaction terminates, or \\
(8b) defaults. \\
(9) the latter happens, CGC is informed and verifies that a \\
default occurred. \\
(10) CGC pays the guaranteed amount (up to 80\%) within 90 \\
days and subrogates to the rights of the financial institution. \\
(11) JFC pays the insurance money to CGC. \\
(12) CGC and the financial institution begin enforcement of \\
their rights against the SME. \\
(13) After the CGC recovers from the borrower to cover the \\
amount of the guarantee, it remits any excess to the JFC.
\end{tabular}

The JFC provides different types of general and special insurance products to CGCs. These products effectively allow the CGCs to transfer the credit risk to the JFC. Special insurance products are directed at transactions where the SME faces some unpredictable challenges, such as a natural disaster or to support new business opportunities. ${ }^{151} \mathrm{JFC}$ provides specific types of insurance to facilitate the use of asset-based lending, including to facilitate restructuring of a business in insolvency. An asset-based lending

${ }^{151}$ Kuroda, supra note 96, at 255. 
(ABL) guarantee was introduced in August 2007. ${ }^{152}$ The insurance ratio is $80 \%$ and the JFC charges a fixed rate of $0.46 \% .{ }^{153}$ However, the ABL guarantee is available only when the loan is secured with liquid collateral, which is defined to include ordinary receivables generated from sales of goods, receivables in the form of promissory notes, electronically recorded receivables and inventory. ${ }^{154}$

Collateral thus plays a role in the ABL guarantee. Overall, collateralization affects the amount of guarantees that may be issued by CGCs, which is limited to 80 million Japanese Yen (JPY). General guarantees may be extended up to 200 to 400 million JPY depending on the type of borrower. ${ }^{155}$

Figure 5: Satisfaction of a Loan Covered by a Credit Guarantee

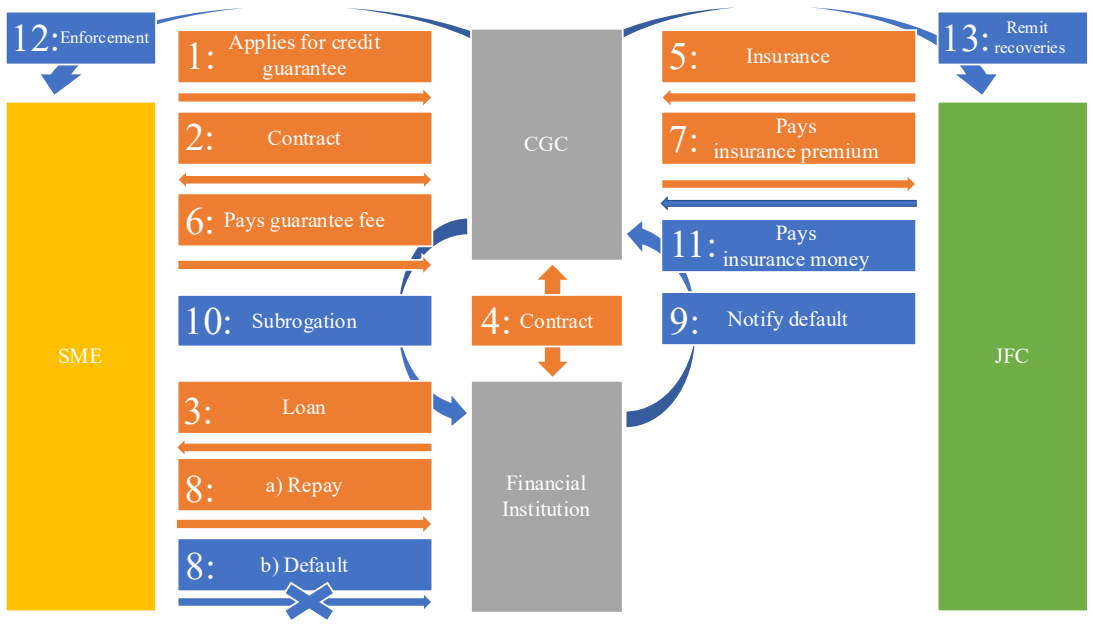

Some earlier studies showed understaffing of the CGCs and the perceived inability to adequately assess guarantee applications. In the Tokyo Guarantee Corporation, the number of approved guarantees per employee was 168 in 2011, while the ratio for employees of private sector banks was forty to eighty loan

${ }^{152}$ Kigyou no Tayouna Sikin Choutatu Shuhou ni Kansuru Jittai Chousa [Research on Diverse Fundraising Methods of Company] 5 (Ministry Econ., Trade \& Indus. (METI) Rsch. Paper, 2019).

${ }^{153}$ Kuroda, supra note 96, at 254.

154 The Small and Medium-sized Enterprise Credit Insurance Act, Law No. 264 of 1950, arts. 3-4; Order for Enforcement of the Small and Medium-sized Enterprise Credit Insurance Act, Cabinet Order No. 350 of 1950, art. 7.

155 JAPAN FED'N CREDIT GUAR. CORPS., supra note 103, at 8. 
approvals. ${ }^{156}$ A 2016 World Bank assessment of sixty credit guarantee schemes found that the global median level is twentynine. ${ }^{157}$

In the Japan Revitalization Strategy 2015, the Small and Medium Enterprise Agency was mandated to "consider creditguarantee system's direction to promote active support by financial institutions to SMEs." Shortly thereafter, the Financial Working Group was established within the Small and Medium Enterprise Policy Making Council, and a year later issued a report "Establishing a Sustainable Credit Enhancement System to Support the Development of Business of SMEs and Small Enterprises." 158 This report recognized the important role of credit guarantees in SME development, contributing to productivity and regional revitalization, but also highlighted the need to minimize side effects. ${ }^{159}$ The Financial Working Group considered the potential effect of reducing the guarantee coverage blanketly from $100 \%$ to $80 \%$, but concluded that such a reduction would not have an impact on the behavior of financial institutions in terms of fostering SME development. A significantly larger reduction might have that effect, but that would risk reduction in overall lending. ${ }^{160}$ Notably, the Tokyo CGC had already introduced an $80 \%$ cap in October 2007. ${ }^{161}$

The 2018 reforms institutionalized the maximum coverage of $80 \%$ of the outstanding loan amount, with the exception of loans to start-ups and microenterprises and for loans extended during a crisis. ${ }^{162}$ Presently, financial institutions have two options as to how to share the risk of loss with CGCs: (i) the partial guarantee method under which $80 \%$ of the outstanding amount is guaranteed and paid upon satisfaction of the prescribed conditions; and (ii) the burden charge method under which $100 \%$ is guaranteed and paid upon

${ }^{156}$ Ono et al., supra note 49 , at 155.

${ }^{157}$ See Calice, supra note 8.

${ }^{158}$ Nobuyoshi Yamori, Japan's Credit Guarantee System Reform of 2017 and New Functions of Credit Guarantee Associations 2-3 (Rsch. Inst. Econ. \& Bus. Admin. (RIEB), Kobe Univ. Discussion Paper Series DP2018-03, Feb. 13, 2018), https://www.rieb.kobe-u.ac.jp/academic/ra/dp/English/DP2018-03.pdf [https://perma.cc/ZWW4-JRMK].

${ }^{159} \mathrm{Id}$. at 3 .

${ }^{160} \mathrm{Id}$. at 4 .

${ }^{161}$ CRedit GuAR. CORP. TOKYO, supra note 104, at 10.

${ }^{162}$ Colacelli \& Hong, supra note 9, at annex 1. 
satisfaction of the prescribed conditions, but later the financial institution pays back a 20\% contribution to the CGC. ${ }^{163}$ A 2019 IMF Working Paper highlighted that the $80 \%$ coverage is still considered high. ${ }^{164}$

If the SME defaults and owes 10 million JPY on a guaranteed loan, the CGC covers $80 \%$, which corresponds to 8 million JPY. The JFC insures $70-90 \%$ (in many cases $80 \%$ ) of the CGC's guarantee which corresponds to 5.6 million to 7.2 million JPY. ${ }^{165}$

Figure 6: Risk Sharing Scheme

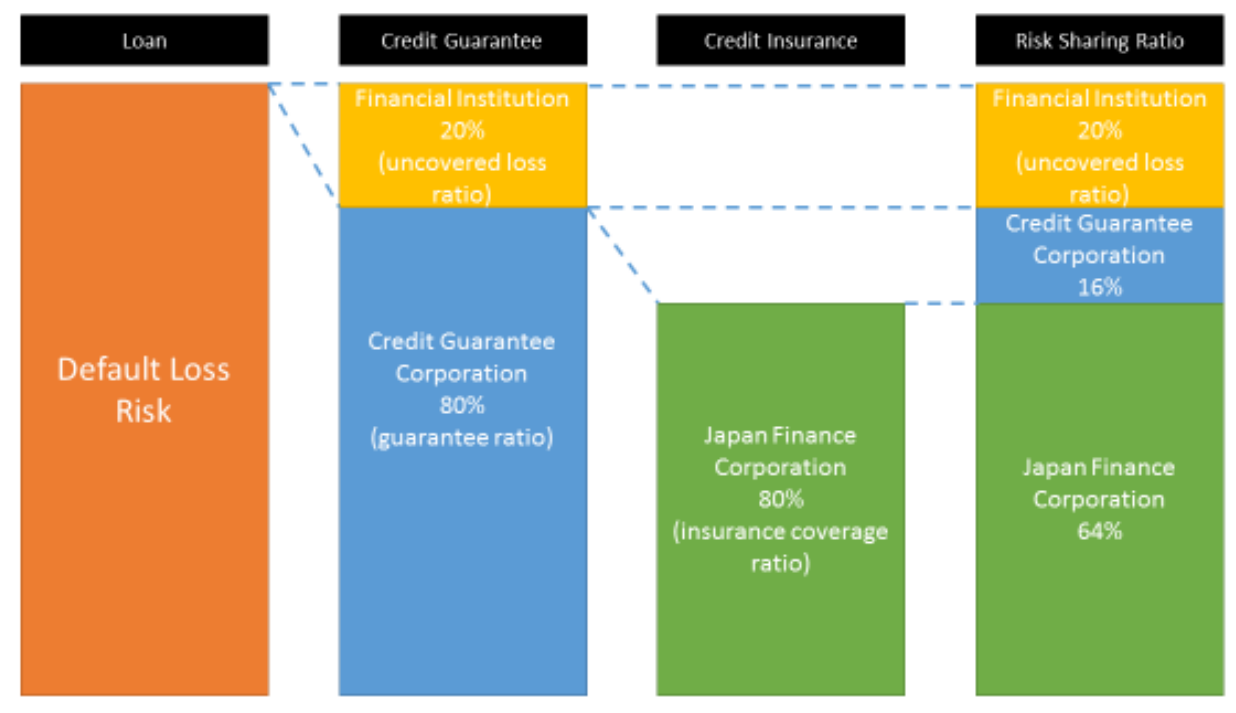

The operations of CGCs are financed primarily by credit guarantee fees, returns on the investment of CGC assets and insurance payments from the JFC. In addition, the national government and local governments, including the Improvement and Promotion of Business Support for SMEs, also provide financial

\footnotetext{
163 JAPAN FED'N CREDIT GUAR. CORPS., supra note 103, at 9.

${ }^{164}$ Colacelli \& Hong, supra note 9, at 9.

${ }^{165}$ Kuroda, supra note 96, at 262.
} 
support to the CGCs to strengthen their financial positions. Financial institutions also provide contributions that are tax deductible. ${ }^{166}$

The guarantee fee is determined at the outset of the transaction, so it does not take into account any changes in the creditworthiness of the borrower. ${ }^{167}$ Additional fees are levied upon default. In 2006, a new system for JFC to collect fees was introduced categorizing borrowers into nine buckets, which was repealed in the aftermath of the 2008 credit crisis when the system reverted to a flat $0.75 \%-0.8 \%$ fee irrespective of the riskiness of the borrower. ${ }^{168}$ Later, the system categorizing borrowers into nine buckets was re-introduced. ${ }^{169}$

\section{Credit Guarantee Programs During Crises}

Guarantee schemes have played an important role during various crises. ${ }^{170}$ The underlying purpose of some schemes is to act as a countercyclical mechanism during crises when financial institutions restrict lending. Unsurprisingly, their role has been amplified during the COVID-19 pandemic. Recognizing that financial institutions are likely to respond to the uncertain economic recovery by limiting lending to reduce risk, the COVID-19 related programs seek to avoid the sharp contraction. ${ }^{171}$

A slew of measures to financially support businesses has been rolled out to address the negative economic impact of COVID-19. ${ }^{172}$ The Bank for International Settlements, IMF, and the World Bank have encouraged regulators to maintain financial stability, market

\footnotetext{
166 Colacelli \& Hong, supra note 9, at 12.

${ }^{167}$ Chau-Jung Kuo et al., Evaluating Guarantee Fees for Loans to Small and Medium-sized Enterprises, 37 SMALL BUS. ECON. 205, 207 (2011).

${ }^{168}$ Colacelli, supra note 9, at annex 1.

${ }^{169}$ Kuroda, supra note 96, at 261.

${ }^{170}$ See KLAPPER \& ZAIDI, supra note 34, at 19 (stating that already existing guarantee scheme provide a read distribution channel for credit).

${ }^{171}$ Patrizia Baudino, Public Guarantees for Bank Lending in Response to the Covid-19 Pandemic, Fin. Stability Inst. BAnK InT'L SETTLEMENTs 1 (Apr. 2020), https://www.bis.org/fsi/fsibriefs5.pdf [https://perma.cc/DJ6T-KMSE].

172 For an overview of the implemented measures, see Tackling Coronavirus (COVID-19) Contributing to a Global Effort, OECD (July 15, 2020), https://www.oecd.org/coronavirus/policy-responses/coronavirus-covid-19-smepolicy-responses-04440101/\#section-d1e7906 [https://perma.cc/36W6-AKDP]; Tatiana Didier et al., Financing Firms in Hibernation During the COVID-19 Pandemic (WBG, Pol'y Rsch. Working Paper No. 9236, May 1, 2020).
} 
functionality, and credit flow while continuing to uphold minimum prudential standards consistent with international standards. ${ }^{173}$ Key elements of measures designed to strike the necessary balance between effective responses and requisite prudence include defining targeted beneficiaries, loan terms, and duration of the program. ${ }^{174}$ Setting a finite duration can limit market distortions when the programs end. ${ }^{175}$ Similar calls and counterbalancing measures with respect to the use of guarantee schemes are noticeably absent.

Credit guarantees deployed during the COVID-19 pandemic have been more generous. A relatively large proportion of these programs cover $100 \%$ of any loss sustained by the lender. ${ }^{176}$ Some programs, including those in Canada and the United States, offer (partial) loan forgiveness for meeting program targets, such as using the loan to pay employee salaries. The United States Paycheck Protection Program and Health Care Enhancement Act allocated 321 billion USD for forgivable loans and guarantees to help small businesses retain workers. ${ }^{177}$ In a complimentary program, the Main Street Business Lending Program (MSLP), the United States Treasury invested 75 billion USD in a special purpose vehicle, established by the Federal Reserve to guarantee $95 \%$ of the par value of loans under the MSLP. ${ }^{178}$

Over the decades, the Japanese Credit Supplementation System has been deployed to tackle the economic downturns caused by several crises. During the recessions of the 1970s and 1980s, as well as the Asian credit crisis of the 1990s, the government utilized credit guarantees to support SMEs through the Special Credit

${ }^{173}$ See Id. at 1, 2; IMF, COVID-19: The Regulatory and Supervisory Implications for the Banking Sector (Joint IMF-World Bank Staff Position Note, May 2020), https://openknowledge.worldbank.org/handle/10986/33793 [https://perma.cc/7XTA-MVHQ].

${ }^{174}$ Baudino, supra note 171, at 1-2.

${ }^{175} \mathrm{Id}$. at 5.

${ }^{176}$ See Id. tbl. 1, at 2 (noting that Hong Kong introduced low-interest loans for SMEs with 100\%government guarantee (HK\$50 billion), and Germany expanded guaranteed loans for companies and credit insurers, including 100\% guarantees for some loans, increasing the total volume by at least $€ 757$ billion (24\% of GDP)).

177 See IMF, Policy Responses to COVID-19, https://www.imf.org/en/Topics/imf-and-covid19/Policy-Responses-to-COVID-19 [https://perma.cc/TW7G-CFMP] (last visited Oct. 22, 2020).

${ }^{178}$ Baudino, supra note 171 , at 6. 
Guarantee Program for Financial Stability ${ }^{179}$ A report published by the Small and Medium Enterprise Agency acknowledged the important role the Credit Supplementation System plays to support the financing of SMEs, particularly in times of crisis. ${ }^{180}$ However, the crisis program was characterized by lenient qualification conditions as a result of which, only a few applications were rejected. ${ }^{181}$ Furthermore, this policy incentivized financial institutions to restructure the unguaranteed loans as guaranteed loans. This practice is now prohibited by the contract between CGCs and financial institutions. ${ }^{182}$ Thus, the program has not resulted in channeling of new credit to SMEs, and increased the moral hazard. ${ }^{183}$

Guarantee programs implemented post the 1998 Asian crisis have been equally ineffective. For instance, the Special Guarantee Program for Financial Stability increased the availability of credit, but it suppressed profitability of borrowers. ${ }^{184}$ After the nation's badloan problem in the 1990s, FSA was established in 1998 under the Ministry of Finance Banking Bureau to administer rule-based strict policy. However, this policy led to homogenization of Japanese financial institutions ${ }^{185}$ and reinforcement of their reliance on guarantees. In October 2008, a guarantee scheme to support SMEs affected by inflationary movements in the price of raw materials and the recession triggered by the global financial crisis was established. ${ }^{186}$ Later, the scheme was expanded to the Emergency Guarantee System providing a financial safety net. The total utilization of the system reached over 27 trillion JPY in March 2011 when it ended. ${ }^{187}$ Another example of addressing a problem caused

${ }^{179}$ Kuroda, supra note 96, at 247.

${ }^{180}$ See SME Credit Supplement System, supra note 37.

${ }^{181}$ Uesugi, supra note 49, at 460.

${ }^{182}$ The Agreement on the Credit Guarantee Corporation Transaction, art. 3.

${ }^{183}$ Hashimoto et al., supra note 71, at 15.

${ }^{184}$ See Uesugi, supra note 49, at 460 (stating that one of the reasons was the moral hazard effect exacerbated by the non-existent collateral requirements).

${ }^{185}$ Hashimoto et al., supra note 71, at 15.

${ }^{186}$ SME Financing Measures Such as the Creation of an Emergency Guarantee for Economic Response, SMALl \& MEDIUM ENTER. AGENCY (Feb. 5, 2010), https://www.chusho.meti.go.jp/kinyu/2010/100205KeikiSupport.htm [https://perma.cc/4UAY-FADX].

${ }^{187}$ Kaori Nakano \& Shinsuke Nakanishi, Lehman Shock Gono Chushokigyo Kinyusiensaku -Chushokigyou Kinyuenkatukahou To Kinkyuhoshou Seido [Policy to Support SME Financing after the Global Financial Crisis-SME 
by an unpredictable event was the scheme implemented in the aftermath of the great earthquake in March 2011. The scheme supported around 3 trillion JPY of business loans. ${ }^{188}$ In April 2018, the Crisis-related Guarantee Scheme was established. ${ }^{189}$ In March 2020, SMEs suffering from the COVID-19 pandemic were listed as eligible. $^{190}$

In the second supplementary budget proposal for the 2020 fiscal year, 12 trillion JPY is proposed to be allocated to strengthen business cash flows as a countermeasure to the COVID-19 effects. ${ }^{191}$ Three trillion JPY will be invested in financing support through private financial institutions, including for credit guarantees and credit insurance. ${ }^{192}$ There is a wide range of support available for SMEs affected by COVID-19, including safety net guarantees No. 4 and No. 5, and the Crisis-related Guarantee Scheme. The Tokyo CGC reported that the amount of guarantees issued from April to August 2020 was 21 trillion JPY. ${ }^{193}$ This exceeds the amount of

Finance Facilitation Act and Emergency Guarantee System], 337 RIPPOU TO

Chousa 62 (2013).

${ }^{188}$ ReCOnStruction Agency, Fukkou no Torikumi to Shoseido [Efforts to Reconstruction and Systems], https:/www.reconstruction.go.jp/topics/maincat7/sub-cat7-2/20190703_sanko2.pdf [https://perma.cc/6J6X-3GD9] (last visited Oct. 24, 2020).

${ }^{189}$ See Kiki Kanren Hoshou Seido [Guarantee System Related to

Emergency], SMall \& MEDiUm ENTER. AGENCY,

https://www.chusho.meti.go.jp/kinyu/sefu_net_crisis.htm [https://perma.cc/3MTN-9VDS] (last visited Oct. 24, 2020).

${ }^{190}$ Singata Corna Virus Kansensho ni Kakaru Chushokigyosha Taisaku wo Koujimasu [We are Implementing Support to SMEs Regarding the Situation of COVID-19], MinisTRY ECON., TRADE \& INDUS. (METI), https://www.meti.go.jp/press/2019/03/20200311007/20200311007.html [https://perma.cc/L87N-ZG8T] (last visited Oct. 24, 2020).

${ }^{191} I d$.

${ }^{192}$ Reiwa2nendo Dai2ji Hoseiyosan no Jigyou Gaiyou [Brief Introduction of 2nd Supplementary Budget for FY 2020], MinisTRY ECON., TRADE \& INDUS. (METI), https://www.meti.go.jp/main/yosan/yosan_fy2020/hosei/pdf/hosei2_yosan_pr.pdf [https://perma.cc/4BDA-BPEY] (last visited Oct. 24, 2020).

${ }^{193}$ Shinyouhoshou Jisseki no suii [Transition in Credit Guarantee Issuance], JAPAN FED. CREDIT GUAR. CORPS., https://www.zenshinhoren.or.jp/document/hosho_jisseki.pdf [https://perma.cc/U26Z-QPP9] (last visited Oct. 24, 2020). 
guarantees issued in the fiscal year in the aftermath of the global financial crisis.

Thus, the credit guarantee system plays an extremely important role as public policy to support SMEs in a crisis where swift government support is needed. These functions and features of guarantees in a crisis differ from guarantees issued in ordinary times. The following table compares guarantees used in ordinary times with guarantees during crises.

\begin{tabular}{|c|c|c|c|c|c|}
\hline & \multicolumn{2}{|c|}{ Ordinary Times } & \multicolumn{3}{|c|}{ Crisis } \\
\hline & $\begin{array}{l}\text { Guarante } \\
\text { e without } \\
\text { collateral }\end{array}$ & $\begin{array}{l}\text { Guarante } \\
\text { e with } \\
\text { collateral }\end{array}$ & $\begin{array}{c}\text { Safety } \\
\text { Net } \\
\text { Guarante } \\
\text { e No.4 }\end{array}$ & $\begin{array}{c}\text { Safety Net } \\
\text { Guarantee } \\
\text { No.5 }\end{array}$ & $\begin{array}{c}\text { Crisis } \\
\text { Related } \\
\text { Guarante } \\
\text { e }\end{array}$ \\
\hline Target & - & - & $\begin{array}{l}\text { SMEs } \\
\text { affected } \\
\text { by } \\
\text { regional } \\
\text { disasters }\end{array}$ & $\begin{array}{l}\text { SMEs } \\
\text { whose } \\
\text { business } \\
\text { classificatio } \\
\mathrm{n} \\
\text { deteriorates }\end{array}$ & $\begin{array}{l}\text { SMEs } \\
\text { affected } \\
\text { by a great } \\
\text { economic } \\
\text { shock or } \\
\text { disaster }\end{array}$ \\
\hline $\begin{array}{l}\text { Use of } \\
\text { funds }\end{array}$ & - & - & $\begin{array}{l}\text { To } \\
\text { stabilize } \\
\text { their } \\
\text { business }\end{array}$ & $\begin{array}{l}\text { To stabilize } \\
\text { their } \\
\text { business }\end{array}$ & $\begin{array}{l}\text { To } \\
\text { stabilize } \\
\text { their } \\
\text { business }\end{array}$ \\
\hline $\begin{array}{l}\text { Guarantee } \\
\text { coverage }\end{array}$ & $80 \%$ & $80 \%$ & $100 \%$ & $80 \%$ & $100 \%$ \\
\hline $\begin{array}{l}\text { Guarantee } \\
\text { fee }\end{array}$ & $\begin{array}{l}0.45 \% \\
\sim 1.90 \% \\
\text { dependin } \\
\mathrm{g} \text { on the } \\
\text { risk }\end{array}$ & $\begin{array}{l}0.45 \% \\
\sim 1.90 \% \\
\text { dependin } \\
\mathrm{g} \text { on the } \\
\text { risk }\end{array}$ & $\begin{array}{l}\text { below } \\
1 \%\end{array}$ & below 1\% & $\begin{array}{l}\text { below } \\
0.8 \%\end{array}$ \\
\hline $\begin{array}{l}\text { Maximum } \\
\text { Amount } \\
\text { Guarantee } \\
\text { d (million } \\
\text { JPY) }\end{array}$ & 80 & 200 & 280 & 280 & 280 \\
\hline
\end{tabular}

\section{EFFECTS OF GUARANTEES}

Public guarantees cause various macroeconomic and microeconomic effects. Some studies identified tax revenue and 
maintaining employment as positive macroeconomic effects. ${ }^{194}$ Others found growth in assets, sales and employment. ${ }^{195}$ In contrast, the OECD has identified a number of market distortions that the use of credit guarantees may generate. These include (i) channeling of funds to unproductive borrowers, ${ }^{196}$ (ii) prolonging the existence of (zombie) companies that should be liquidated, ${ }^{197}$ (iii) preventing the diversification of various financing sources, ${ }^{198}$ (iv) disadvantaging companies that are ineligible to access credit guarantees; and (v) creating contingent fiscal liabilities. ${ }^{199}$

The design of the Japanese Credit Supplementation System is prone to creating these negative effects. The OECD found that it hinders market-based financing, creates disincentives to grow, and delays restructuring of viable businesses. ${ }^{200}$ Studies by local commentators found that SMEs that benefit from guaranteed loans experience declines in their financial performance, and the asset composition of guarantee beneficiaries changes very little, which

${ }^{194}$ See Chatzouz et al., supra note 93, at 11 (noting that in the United States, the SBA program benefitted employment in low-income areas only); Craig et al., supra note 1, at 346, 357 (describing this impact as significantly higher in markets with small businesses owned by minorities); Ben R. Craig et al., Small Firm Credit Market Discrimination, Small Business Administration Guaranteed Lending, and Local Market Economic Performance, 613 ANNALS AM. ACAD. POL. Soc. SCI. 73 (2007) (advancing research on minority entrepreneurship).

${ }^{195}$ A study of the EU market found that within two years after receipt of a guaranteed loan, the growth of SME beneficiaries exceeded those whose loans were not guaranteed in a number of metrics: assets by $19.6 \%$, sales by $14.8 \%$ and employment by $16.9 \%$. Fabio Bertoni et al., Econometric Study on the Impact of EU Loan Guarantee Financial Instruments on Growth and Jobs of SMEs 9 (Eur. Inv. Fund Working Paper No. 2019/54, 2019).

${ }^{196}$ In Chile, guarantees increase delinquency rates by $1.5 \%$ within the first 12 months, and by $2 \%$ within 24 months as compared to unguaranteed loans. Kevin Cowan et al., The Effect of Credit Guarantees on Credit Availability and Delinquency Rates, 59 J. BANKING \& FIN. 1, 3 (2015).

197 See Commission Notice, supra note 123, at $\$ 2.2$.

198 See also USAID, FrOM LAWS TO LOANS, supra note 19, at 37.

${ }^{199}$ Evaluating Publicly Supported Credit Guarantee Programmes for SMEs, OECD, at 9 (2017).

${ }^{200}$ Randall S. Jones \& Myungkyoo Kim, Promoting the Financing of SME's and Start-ups in Korea 12 (OECD Econ. Dep't Working Papers No. 1162, Sept. 16, 2014), https:/www.oecd-ilibrary.org/economics/promoting-the-financing-ofsmes-and-start-ups-in-korea_5jxx054bdlvh-en [https://perma.cc/3HGA-AG5K]. 
suggests that guaranteed loans may be used to fund operating losses. ${ }^{201}$

Businesses with great potential that may be informationally opaque are unable to access guaranteed loans. Guarantee schemes have a tendency to support businesses with negative growth prospects, as long as they have a history of benefitting from guarantees. ${ }^{202}$ The continued availability of a guarantee, in its present structure, does not provide sufficient economic incentives to liquidate or restructure a struggling borrower and revive its business prospects. The lending bank is incentivized to preserve the relationship it has built with the borrower, which liquidation would effectively terminate. The CGC and JFC are public entities whose mission may be questioned if an increasing number of Japanese SMEs were liquidated. Accordingly, the incentive structure is designed for the CGC and JFC to be reluctant to force liquidation of unviable borrowers.

Japanese borrowers who secured the repayment of their loans with some collateral experience larger increases in profitability and improvement in their risk profile. ${ }^{203}$ The 2018 JFC Annual Report includes a story recounted by the honorary chairman of Kyocera Corporation, now a company publicly traded on the Tokyo Stock Exchange. Forty years ago, a local branch of JFC extended a loan to Kyocera secured with the machinery it was planning to buy in the future. $^{204}$ This loan enabled Kyocera to grow its business to its present size. This is a good illustration of the economic effect of lending secured with commercial collateral that the Credit Supplementation System used to enable.

${ }^{201}$ See Imai, supra note 52, at, 13. See also Uesugi et al., supra note 49, at $458,479$.

202 See Jae Won Kang \& Almas Heshmati, Effect of Credit Guarantee Policy on Survival and Performance of SMEs in Republic of Korea, 31 SMALL Bus. ECON. 445, 451-58 (2008); Atsushi Kakinuma \& Shinsuke Nakanishi, Zaisei Futan no Shiten kara Mita Shinyou Hoshou ni Kansuru Ichi Kousatu [Consideration on Credit Guarantee Regarding the Public Financial Burden], KeIZAI NO PRISM 114, 140 (2013).

${ }^{203}$ See Arito Ono et al., The Effects of Collateral on Firm Performance, 26 J. JAPANESE INT'L ECON. 84, 84-85 (2012) (describing how the lack of collateral reduces the incentive of the borrower to operate its business in the most efficient manner, and encourages asset substitution and dissipation); Ono et al., supra note 49 , at 154

${ }^{204}$ See JFC, supra note 98 , at 50. 
A 2016 report by the Asian Development Bank (ADB) contends that:

in practical terms guarantees are not a substitute for being able to secure loans against collateral. All the problems with unsecured lending exist with guarantees. All that a guarantee does is shift the risk, or some percentage of the risk, from the primary lenders, the banks, to the guarantors. . . . There is simply no substitute for reform of secured transactions systems if financial markets are to adequately fund small and medium sized businesses. ${ }^{205}$

\section{Borrowers and Lenders}

The availability and low cost of credit guarantees do not make market-based financing an economically attractive alternative in Japan. ${ }^{206}$ Even though market-based financing produces a number of positives for borrowers, the incentive structure steers them to guaranteed lending. Furthermore, the incentive structure locks in the SME borrower within the Credit Supplementation System. Put simply, business growth punishes the borrower because outgrowing its SME status makes it ineligible to participate in a guarantee scheme. Lenders have an incentive to preserve the SME status of their borrowers so as not to lose the benefit of the guarantee, without which lending becomes riskier. ${ }^{207}$ This distortion is one of the failures of size-dependent policies in Japan. ${ }^{208}$

The statistics on the use of credit guarantees illustrate these failures. Figure 7 documents that $95.6 \%$ of all guaranteed loans are under 80 million JPY, which is the maximum amount eligible for JFC insurance for loans that do not require any collateral. Figure 8 illustrates that $93.7 \%$ of all guaranteed loans are used for working

${ }^{205}$ ASIAN DEV. BANK, CREDIT GUARANTEES: CHALlENGING THEIR RolE IN IMPROVING ACCESS to FINANCE IN THE PACIFIC REGION 9 (2016).

${ }^{206}$ Ono, Role of Collateral and Personal Guarantees, supra note 67, at 942.

${ }^{207}$ Daisuke Tsuruta, SME Policies as a Barrier to Growth of SMEs, 54 SMALL Bus. ECON 1067, 1076 (2020).

${ }^{208}$ Id. at 1072, 1100. 
capital rather than investment. ${ }^{209}$ Accordingly, lenders extend loans that fall under the maximum that does not require taking any collateral, and borrowers use the loan proceeds to essentially maintain and preserve their business.

Figure 7: The Amount of Guaranteed Loan

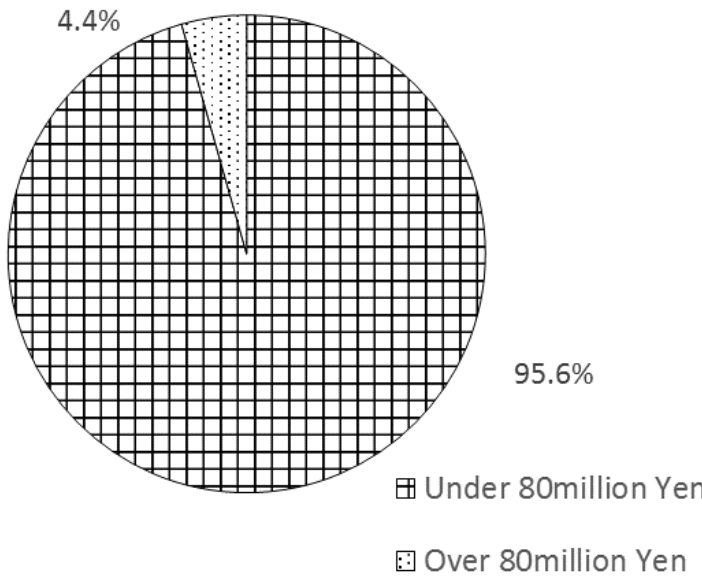

Figure 8: Usage of the Guaranteed Loan

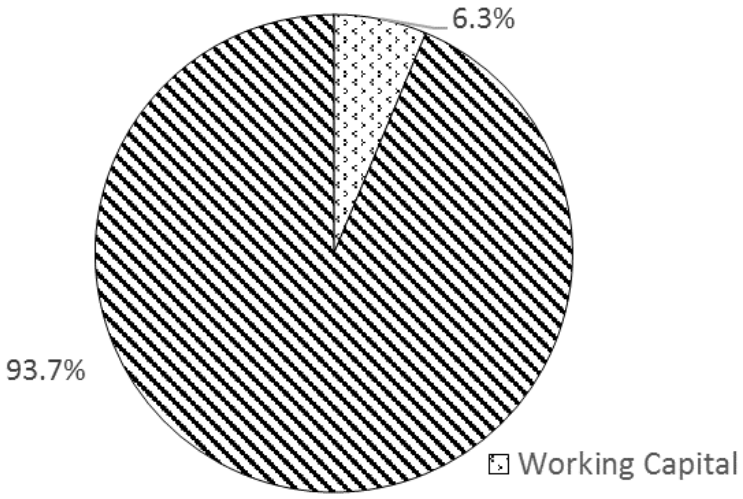

$\mathbf{\Delta}$ Capital Investment and others

While the guarantee scheme does not require lenders to ease the requirements to take collateral, guarantees result in lower collateral requirements. The use of collateral for lending is predicated on the ability of the lender to administer the loan as well as value and monitor the collateral. The Bank of Japan highlighted that the risk management for loans to middle-risk businesses in Japan must be strengthened. ${ }^{210}$ Inadequate practices and skills of this nature are also characteristic for CGCs and JFC. ${ }^{211}$ If the risk of the lender is $100 \%$ covered by a guarantee, even if the loan is secured by

${ }^{209}$ See JAPAN Fed'N CREdit GuAR. CORPS., Heisei 30 Nendo Sinyou

Hoshou Riyoujoukyo [Usage of Credit Guarantee in FY2018],

http://www.zenshinhoren.or.jp/document/riyo_jyokyo.pdf

[https://perma.cc/U5XU-YP42] (last visited Oct. 24 2020).

${ }^{210}$ BANK OF JAPAN, supra note 54, at 84.

${ }^{211}$ The JFC does not perform any due diligence on the borrowers whose loans are guaranteed by the CGC, but does so for the loans it directly extends. In the former case, the CGC and the lender assess the creditworthiness of the loan applicant. 
collateral, the incentives to build capacity to administer and monitor such loans are reduced. ${ }^{212}$ This incentive is further reduced by the policy of CGCs that requires the application of less strict valuation methods when some collateral is taken. ${ }^{213}$

The design of the Japanese guarantee scheme disincentivizes the building of skills necessary to administer secured loans and halts the transition to market-based financing. The other major effect is to perpetuate the existence of zombie companies. The 2013 Japan Revitalization Strategy set a goal to increase the percentage of nonviable firms that should be liquidated and entry of new firms from 4$5 \%$ (it was below $4 \%$ in 2012) to $10 \% .^{214}$ If a loan is guaranteed and restructuring has no effect on the continuation of the guarantee coverage, lenders have an economic incentive to inject liquidity into a zombie company that should have been liquidated. If the loan is not guaranteed, there is more of an incentive to provide debt forgiveness. Japanese lenders do not have an economic incentive to forgive the debt on which its potential losses are $80 \%$ or $100 \%$ guaranteed. ${ }^{215}$ It has been documented that the financial performance of borrowers whose indebtedness has been forgiven is superior as compared to those who receive an extension of the guaranteed loan. For those companies remaining in the guarantee scheme, leverage

${ }^{212}$ See Le Ngoc Dang \& Anh Tu Chuc, Challenges in Implementing the Credit Guarantee Scheme for Small and Medium-Sized Enterprises: The Case of Viet Nam 14 (Asian Dev. Bank Inst., Working Paper No. 941, 2019); Commission Notice, supra note 123, at § 3.2(c). See also Arito Ono, Chushokigyo Muke Kashidasi wo Meguru Jishoubunseki: Genjou to Tenbou [Empirical Analysis on SME Lending: Present and Prospect], 30 KIN'YU KENKYU (2011) (describing how the financial institution may still bear the borrower's credit risk when it has extended multiple loans to that same borrower); Ono \& Uesugi, supra note 67, at 935, 943.

${ }^{213}$ For receivables, CGC requires establishment of their value by applying a percentage that varies from $70 \%$ to $100 \%$ of average monthly sales that generate the receivables. For inventories, the book value can be used. Based on this evaluation, the applicable loan amount is $30 \%$ of the asset value. The weight can be increased from $30 \%$ to $70 \%$, such as when the asset's value is objectively established by a third party. See JAPAN FED'N CREDIT GUAR. CORPS., HOSHOUTSUKI YUSHI TORIATUKAI Q\&A [HOW TO TREAT GUARANTEED LOANS Q\&A] 232 (2011).

${ }^{214}$ See also Jones \& Jin, supra note 62, at 11; Colacelli \& Hong, supra note 9 , at 9 .

${ }^{215}$ Ono \& Yasuda, supra note 30 , at 5. 
increases, credit profiles deteriorate, and number of employees declines. ${ }^{216}$

\section{Realignment of the Incentives}

Lenders and borrowers have ample incentives to participate in the Credit Supplementation System. Those are reinforced not only by the overall risk transfer to the guarantee scheme, but also the types of obligations that lenders must perform to claim protection. Examination of agreements between the CGC and lenders reveals that the agreements are not set up to induce lenders to build capacity to administer commercial loans. ${ }^{217}$ Several examples will illustrate.

The lender is required to proceed with due diligence, in accordance with the agreement it signs with the CGC. ${ }^{218}$ In case of a deterioration of the credit facility or impending default, it would ordinarily inform the CGC and take any steps necessary to preserve recourse against the borrower. After making a payment to the lender and subrogation to its rights, the CGC would pursue the borrower. The outstanding obligation owed by the borrower typically includes any amount the CGC paid on the guarantee, costs of enforcement, and damages for the breach of the agreement. Since the guarantee generally covers $80 \%$ of the outstanding amount of the obligation, the

\footnotetext{
${ }^{216} I d$. at 4 .

${ }^{217}$ The Agreement on the Credit Guarantee Corporation Transaction is on file with the authors.

${ }^{218}$ Financial institutions are required to exercise the due diligence necessary to ensure the satisfaction of the credit guaranteed obligation under The Agreement on the Credit Guarantee Corporation Transaction, art. 9. However, some research pointed out that the vagueness of the contract is resulting in the failure to exercise proper due diligence and monitoring by the financial institutions. For further information, see Shunkichi Tsurui \& Masayoshi Hirano, Shinyou Hosho Kyoukai Torihihiki no Houteki Saikousei (1)—21 Seiki heno Kinyu Henkaku no Nakadeno Kouteki Hoshou Kikan Torihiki to Kongo [Reconstructing a Framework of Legal Aspects of Transactions with Public Guarantee Organizations (1)-Transactions with Public Organizations amid the Deregulation on Japanese Banking IndustryDesigning a Desirable Future Framework], Komazawa Hougaku 9, 262-215 (2009); Shunkichi Tsurui \& Masayoshi Hirano, Shinyou Hosho Kyoukai Torhihiki no Houteki Saikousei (2)_21 Seiki heno Kinyu Henkaku no Nakadeno Kouteki Hoshou Kikan Torihiki to Kongo [Reconstructing a Framework of Legal Aspects of transactions with public guarantee organizations (1) - Transactions with Public Organizations amid the Deregulation on Japanese Banking Industry-Designing a Desirable Future Framework], Komazawa Hougaku 9(2), 200-89 (2009).
} 
lender is expected to enforce its rights against the borrower for the deficiency. Accordingly, the borrower may be subject to two competing enforcement actions-CGC's for the $80 \%$ of the outstanding amount it paid to the lender and the $20 \%$ of the outstanding amount, which represents the lender's deficiency. The borrower may not have sufficient assets to satisfy both claims, in which case their priority will matter. In the absence of a specific clause in an agreement between the CGC and the lender as to the priority of their respective claims, the ordinary first-in-time, first-inright principle would apply. Accordingly, the deficiency claim of the lender would be satisfied in priority that further distorts its incentives in administering the loan. One way in which the enhancement of practices of lenders may be induced is for the JFC and CGCs to consider including subordination clauses in their agreements with that would subordinate the deficiency claims of lenders to the enforcement of subrogation rights of the issuers of guarantees to the extent of the proportional sharing of the loss $80 / 20 \%$.

Another example is the CGCs' right to refuse the payment on a guarantee. The effectiveness of the "exemption clause" that allows the CGC to reject a claim for the payment of a guarantee was addressed by the Supreme Court of Japan in its (Ju) 1351 of 2014 decision. ${ }^{219}$ In that case, the lender failed to conduct proper due diligence on the personal guarantor of the loan who served as the director of the company borrower. The Supreme Court held that a lender that failed to investigate whether the undertaking of the director will be valid and enforceable amounts to a breach of the guarantee agreement that exempts the CGC from paying the guaranteed amount. In another case, the Supreme Court held that CGC guarantees may not be used to satisfy the borrower's other indebtedness to the lender. ${ }^{220}$ The lender applied the sum paid by the CGC first to an unsecured overdraft and then the remainder on the actual loan that was guaranteed. The Supreme Court held that such use of the guarantee is contrary to its purpose, and breach of a clause in a contract between the $\mathrm{CGC}$ and the lender that precludes

\footnotetext{
${ }^{219}$ Minshu Vol. 70, No. 1.

${ }^{220}$ The Agreement on the Credit Guarantee Corporation Transaction, art. 3. See JAPAN FED'N CREDIT GUAR. CORPS., supra note 103, at 278-79.
} 
"replacement of old loans with new guaranteed loans."221 Such a breach would partially extinguish the liability of the CGC to pay the guaranteed sum corresponding to the breach. Thus, the lender may still claim a payment from the CGC for the amount that corresponds to the outstanding obligation of the borrower on the guaranteed loan that is less of an incentive to exercise due diligence.

Notably, CGC rejections of claims on the guarantees by lenders are extremely rare. The Supreme Court decisions protect the CGC against lapses of lenders that ordinarily should not occur. The narrow grounds that would entitle the CGC to refuse a claim reinforce the lax attitude of financial institutions towards doing due diligence on prospective borrowers.

The lender may expect to be paid if it merely acts in good faith, and what elsewhere may fall short of commercially reasonable conduct. 222 The conditions and minimal grounds for refusing to honor a guarantee set out in agreements with the CGC inevitably impact lending practices. As a condition of participation in the Credit Supplementation System, lenders should be required to issue, administer, and liquidate guaranteed loans consistent with prudent lending standards. The Agreement on the Credit Guarantee Corporation Transaction between the CGC and the financial institution, specifically articles 9-11, detail the protection and collection of guaranteed obligations including provision of collateral and exemption from responsibility. ${ }^{223}$ However, the guideline is not as detailed as the guidelines issued in the United States by the SBA with respect to servicing loans and liquidating collateral supporting loans guaranteed by the SBA. ${ }^{24}$

CGCs may consider issuing more detailed guidelines identifying certain actions that should be taken by lenders. These

\footnotetext{
${ }^{221}$ Saiko Saibansho [Sup. Ct.] OCT. 31, 1997, Hei 19 no. 9. SAIKO SAIBANSHO MINJI HANREISHU [MINSHU] 4004.

${ }^{222}$ Cf. U.C.C. § 9-610(b) (Am. Law. Inst. \& Unif. Law Comm’n 1977) (requiring all aspects of disposition of the collateral to be in a "commercially reasonable" manner). See also Comm'n Int'l Trade Res. 61/33, at art. 4 (Dec. 4, 2006) (discussing the relationship between knowledge and compliance when waiving one's right to object in international arbitration).

${ }^{223}$ Credit Guarantee Corporation, Yakujoushorei no Kaisetsu to Kaishakushishin (art. 9-11) (interpreting guidelines of the agreement on the credit guarantee corporation transactions).

${ }^{224}$ For a sample applicable to U.S. lenders, see OFFICE OF CAPITAL ACCESS, SBA 50-57-2, 7(A) LOAN SERVICING AND LIQUIDATION (2015),
} 
guidelines would be particularly desirable for loans secured with personal property. ${ }^{225}$ They may relate to administering loans, such as to require lenders to collect from the borrower information affecting the business, including any changes in the name and location, whether of the borrower itself or any personal guarantor, as well as any financial information material to the operation of the business. But, also, they may prescribe certain actions to be taken to facilitate orderly liquidation of the collateral. The CGC may prepare liquidation plans outlining the steps necessary for lenders to enforce their rights in the collateral. ${ }^{226}$ These plans should be incorporated in the contract between the CGC and financial institutions, which should also provide for the priority of the CGCs' deficiency claims. Upon default, the collateral should be inspected, inventoried and valued. Lenders should be required to take any necessary actions to preserve the collateral value, whether prior to or during insolvency. A liquidation plan for different types of collateral may give lenders the necessary comfort as well as nudge them toward timely liquidation of zombie companies rather than preserving their existence. The CGC should be released from liability on a guarantee if the lender has failed to make, close, service, or liquidate a loan in a prudent manner or if the lender's improper action or inaction has exposed the CGC to risk. ${ }^{227}$

Changes should be considered not only at the contractual but also at the functional level. The Credit Supplementation System should consider becoming more of a facilitator of private transactions. For example, one reason lenders shy away from secured lending is the challenge of asset valuation. To incentivize lenders to engage in secured transactions, the CGCs should explore the use of modern technology to design secondary markets for collateral that would increase the re-sale value of assets. The CGCs could establish a digital platform where receivables of large companies may be posted to enable their financing by interested parties. This mechanism of

${ }^{225}$ See Credit Guarantee Corporation, Yakujoushorei no Kaisetsu to

Kaishakushishin (art. 9-11) (interpreting guidelines of the agreement on the credit guarantee corporation transactions).

${ }^{226}$ Office of Capital Access., supra note 224.

${ }^{227}$ Cf. 13 C.F.R. $\$ 120.524$ (2019) (deatiling the grounds that entitle the United States Small Business Administration to deny paying on the guarantee it has issued). 
reverse factoring has been deployed elsewhere by agencies similar to Japanese CGCs. ${ }^{228}$

\section{COnClusions}

State interventions are deployed to address market failures impacting access to credit. They should not be designed simply for the purpose of increasing the use of financial services per se. Furthermore, they should correct the underlying problems in a costeffective and complementary manner to market-based financing. ${ }^{229}$ Several interventions have had negligible economic impact in Japan's history and were discontinued. In contrast, credit guarantees support about one third of SME credit in Japan. They fulfill various policy goals, including stability of the labor market. Any reconfiguration of the Japanese credit market toward market-based financing must take into account the enormous economic significance of the guarantee scheme, its role during crises, including the COVID-19 pandemic, and its foothold in various facets of the economy.

The policy underpinning a guarantee scheme should not be to increase the amount of finance but to facilitate the use of finance in a more productive manner. This effect has been lacking in Japan. The OECD recommended shifting the focus from providing a safety net for borrowers, particularly those negatively affected by a (financial) crisis, including COVID-19 pandemic, to efficient market-based financing that, among others, facilitates restructuring of struggling businesses. ${ }^{230}$ This shift should be accompanied by increasing the availability of financing instruments to SMEs. Transition to marketbased financing is expected to increase the productivity and growth of SMEs, and facilitate the exit of economically unviable companies. Various Japanese agencies highlighted that borrowers should "graduate" from credit guarantees, recommending prioritization of support for conventional bank loans.

The guarantee scheme in Japan should consider some modifications to assist the development of market-based secured financing. First, some evidence of inability to obtain an unguaranteed

\footnotetext{
${ }^{228}$ See eg., DE LA TORRE ET AL., supra note 16, at 147-65 (describing the impact of such practices in Mexico).

${ }^{229} \mathrm{Id}$. at 164.

${ }^{230} \mathrm{See}$ COVID-19 GOVERnMENT FINANCING SUPPORT PROGRAMMES FOR BUSINESSES, OCED 15 (2020).
} 
loan may be required. If the prospective borrower already meets the lender's standard criteria for a market-based loan, a guarantee is unjustified. JFC and CGCs may consider requiring some evidence of the prospective borrower not being able to satisfy those criteria as a condition of issuing the guarantee. This would enable the policymakers to also assess the financial additionality effect of the scheme. ${ }^{231}$ Second, a business may be entitled to access a guaranteed loan only one time, unless it has demonstrated growth in productivity while it remains unable to obtain a loan not supported through the Credit Supplementation System. Third, access to guarantees may be limited primarily to those borrowers who have not established a relationship with a financial institution, such as start-ups. ${ }^{232}$ Fourth, guarantees may be used side-by-side with security interests in movable assets, but designed to gradually facilitate the transition to secured loans for which a guarantee is unnecessary. Such collateral should not be limited to inventory and receivables, which are the only types that currently qualify as liquid assets in Japan, but also include equipment and intellectual property rights. Fifth, in exchange for restructuring the guaranteed loan, the borrower should provide additional collateral. An extension of a credit guarantee sustains the existence of unproductive zombie companies. Sixth, the value of collateral securing the loan may translate into a reduction in the fee for the issuance of a guarantee. Finally, a higher fee may be imposed on the lender that has a track record of extending loans with a high default rate.

The Credit Supplementation System should promote a credit culture in which lenders develop prudent lending practices and maintain relationships with borrowers. This would directly address the inadequate risk assessment capacity of Japanese lenders. Without such capacity being sufficiently developed, an increase in asset-based lending should not be expected. However, all of these changes will have the desired economic effect only if the secured transactions framework is aligned with the international principles. An effort to reform that framework is ongoing, and the recovery from the COVID-19 pandemic presents an opportunity to redefine the role of

${ }^{231}$ See Abraham \& Schmukler, supra note 31 (noting that the financial additionality measures increase in access to credit and improved lending conditions).

${ }^{232}$ Ono et al., supra note 49 , at 166. 
the Credit Supplementation System in enabling market-based financing. 